University of Nebraska - Lincoln

DigitalCommons@University of Nebraska - Lincoln

\title{
Stockwork Tungsten (Scheelite)-Molybdenum Mineralization, Lake George, Southwestern New Brunswick
}

Robert R. Seal II

U.S. Geological Survey, 954 National Center, Reston, Virginia 20192, USA, rseal@usgs.gov

Alan Clark

Department of Geological Sciences, Queen's University, Kingston, Ontario, Canada K7L 3N6

Charles Morrissy

Durham Resources, Inc., Prince William, New Brunswick, Canada EOH 1 SO

Follow this and additional works at: https://digitalcommons.unl.edu/usgsstaffpub

Part of the Earth Sciences Commons

Seal, Robert R. Il; Clark, Alan; and Morrissy, Charles, "Stockwork Tungsten (Scheelite)-Molybdenum Mineralization, Lake George, Southwestern New Brunswick" (1987). USGS Staff -- Published Research. 343.

https://digitalcommons.unl.edu/usgsstaffpub/343

This Article is brought to you for free and open access by the US Geological Survey at DigitalCommons@University of Nebraska - Lincoln. It has been accepted for inclusion in USGS Staff -- Published Research by an authorized administrator of DigitalCommons@University of Nebraska - Lincoln. 


\title{
Stockwork Tungsten (Scheelite)-Molybdenum Mineralization, Lake George, Southwestern New Brunswick
}

\author{
Robert R. Seal II, Alan H. Clark, \\ Department of Geological Sciences, Queen's University, Kingston, Ontario, Canada K7L 3N6 \\ AND CHARLES J. MORRISSY \\ Durham Resources, Inc., Prince William, New Brunswick, Canada EOH 1 SO
}

\begin{abstract}
Scheelite-molybdenite stockwork mineralization constitutes one component of the Lake George polymetallic (Sb-W-Mo-Au-base metal) deposit, a complex hydrothermal center of Late Silurian (ca. 412 m.y.) age in the Fredericton trough of the northern Appalachians. The stockwork, hosted by Silurian graywackes, in part calcareous, is spatially and temporally related to a postkinematic cupola of biotite monzogranite, and its formation overlapped in time with the emplacement of monzogranitic porphyry dikes. Mineralogical and textural evidence indicates that contact metamorphism associated with the cupola had ceased before the initiation of W-Mo mineralization and that it occurred, at pressures of less than $1.75 \mathrm{~kb}$, in two stages: a peak stage $\left(\mathrm{T}>600^{\circ} \mathrm{C}\right)$, evident only in rocks of pelitic composition; and a lower temperature reequilibration $\left(\mathrm{T}<500^{\circ} \mathrm{C}\right)$, recorded in rocks of both pelitic and marly compositions.

The W-Mo deposit comprises three different scheelite- and/or molybdenite-bearing veinlet types. Type 1 bodies, the earliest formed, are calc-silicate (granditic garnet, wollastonite, clinopyroxene, and calcic amphibole) quartz veinlets, with ubiquitous $\mathrm{Ca}$ and $\mathrm{H}$ metasomatic alteration envelopes. Mineralogical and fluid inclusion relationships indicate that the fluids ranged in temperature from $550^{\circ}$ to $228^{\circ} \mathrm{C}$ and that temperature decreased away from the cupola. The succeeding type 2 veinlets comprise quartz and lesser amounts of perthitic alkali feldspar, muscovite, calcite, scheelite, molybdenite, and pyrite. Fluid inclusion evidence shows that mineralization dominantly occurred from $400^{\circ}$ to $175^{\circ} \mathrm{C}$, under a confining pressure of $1.3 \mathrm{~kb}$. Higher grade scheelite and molybdenite deposition was focused in a lower temperature zone, to the north of the cupola, in which $\mathrm{CO}_{2}$ effervescence occurred. Type 3 veinlets, the last to form, consist of prehnite, molybdenite, and quartz and represent a volumetrically minor mineralization type.

In both type 1 and 2 systems, scheelite and molybdenite deposition appears to have been controlled by decreasing temperature and increasing $\mathrm{pH}$. Temperature was a function of distance from the cupola for both veinlet types, but the controls on $\mathrm{pH}$ were specific to each. Thus, the $\mathrm{pH}$ of type 1 fluids was controlled by wall-rock interaction ( $\mathrm{H}$ metasomatism), whereas that of type 2 fluids was controlled by $\mathrm{CO}_{2}$ effervescence.

The economic stibnite-quartz veins (Scratch et al., 1984) occupy fractures which transect, and therefore, postdate all stages of $\mathbf{W}$-Mo mineralization.
\end{abstract}

\section{Introduction}

THE Lake George mine, the major North American producer of antimony in recent years (Morrissy and Ruitenberg, 1980; Scratch et al., 1984), also constitutes a potentially important source of scheelite and molybdenite. The mine, owned by Durham Resources, Inc., is located at lat $67^{\circ} 02^{\prime} \mathrm{N}$, long $45^{\circ} 51^{\prime}$ W, in York County, New Brunswick, approximately $35 \mathrm{~km}$ southwest of Fredericton (Fig. 1).

In 1970, Durham Resources, Inc., began mining at the Lake George site on the east-west-striking, northdipping Hibbard vein and have produced approximately one million metric tons of ore grading 3.0 to

\footnotetext{
- Present address: Department of Geological Sciences, University of Michigan, Ann Arbor, Michigan 48109.
}

3.5 percent $\mathrm{Sb}$ from the orebody 1 (Morrissy and Ruitenberg, 1980). In 1981, Durham Resources delimited orebody 2 (ca. 800,000 metric tons grading $4.15 \% \mathrm{Sb}$ ) on the Hibbard vein, downdip from, and to the west of, the existing mine workings (Ellis, 1983).

During the exploratory drilling for the second orebody, an extensive zone of scheelite and molybdenite mineralization, hosted by calc-silicate and quartz veinlets, was encountered in both the hanging wall and footwall of the Hibbard vein. Recent development (1984-85) has also revealed a concentration of sphalerite-rich stibnite-calcite-quartz veinlets in the footwall of the Hibbard vein. They contain minor galena, arsenopyrite, bismuthinite, native bismuth, and native gold, as well as minor scheelite. 


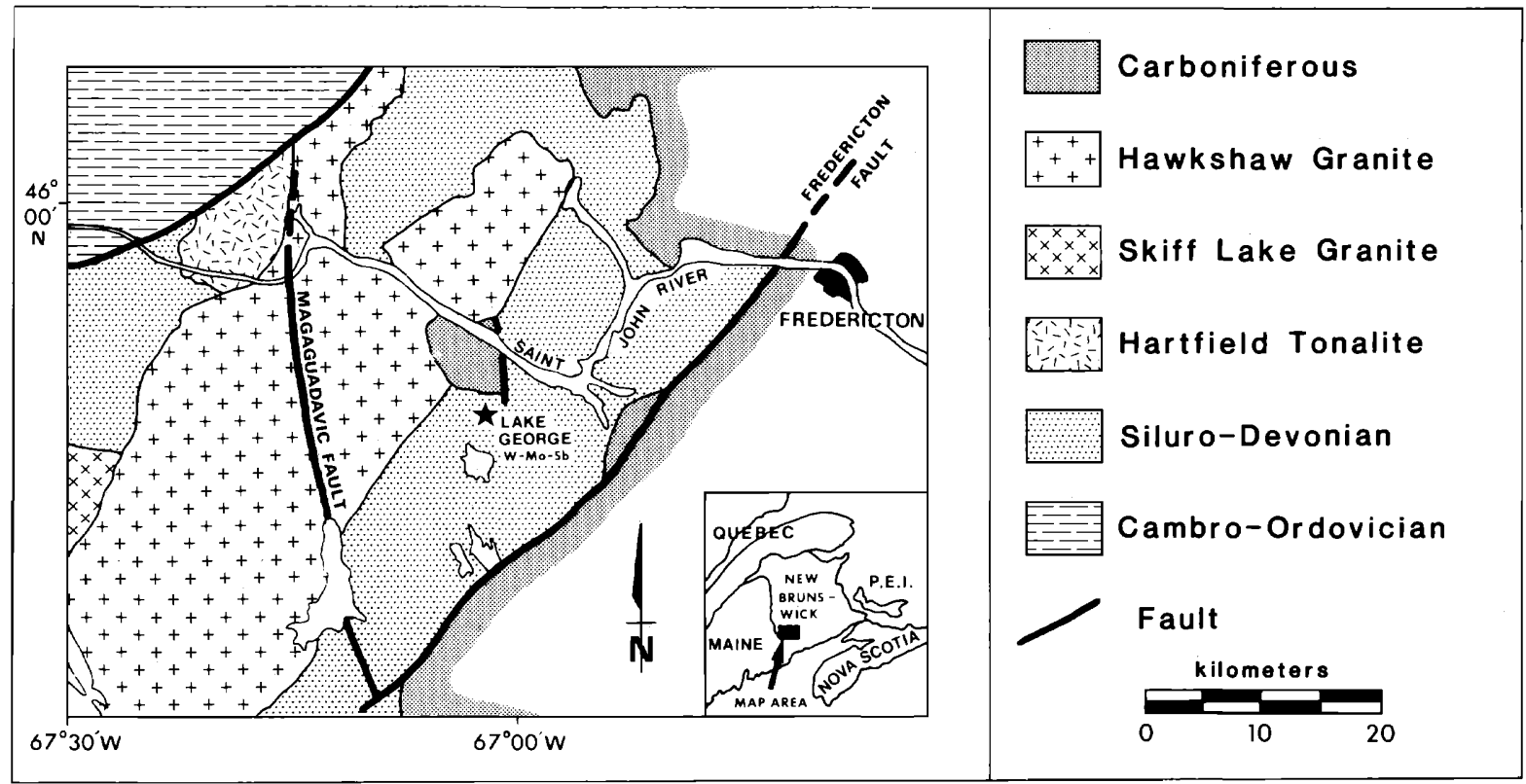

FIG. 1. Location of Lake George mine and district geology (simplified after McCutcheon et al., 1981).

The present paper focuses on the W-Mo stockwork mineralization. New observations on the $\mathrm{Sb}$ veins and an assessment of the overall temporal and genetic relationships of the various ore-types in this polymetallic center are presented elsewhere (Seal et al., 1985b; and in press).

\section{Regional Geology}

The Lake George deposits are hosted by Silurian turbiditic sediments of the Magaguadavic subzone (Ruitenberg et al., 1977). The area is characterized by tight folds and northeast-trending axial-planar cleavages, produced by penetrative deformation and accompanying lower greenschist facies regional metamorphism, all assigned to the $D_{1}$ phase of the Acadian orogeny (Ruitenberg and McCutcheon, 1982). Subsequently, the area was intruded by the polyphase Pokiok batholith, considered to be Early Devonian in age (ca. 390 m.y.; McCutcheon et al., 1981). The Hawkshaw monzogranite, the youngest phase of the batholith, crops out within $3 \mathrm{~km}$ of the mine site (Fig. 1).

During the Carboniferous, the metasedimentary and intrusive rocks of the Magaguadavic subzone were unconformably covered by continental sediments and volcanics (Fig. 1), which have remained essentially undeformed (Ruitenberg et al., 1977).

\section{Local Geology}

\section{Metasedimentary rocks}

The turbiditic metasediments which host the Lake George deposits include graywackes, sandstones, siltstones, and black, nongraphitic slates; all units contain varying amounts (up to $40 \%$ ) of carbonate. The occurrence of calcareous graywackes and siltstones in the mine area, in addition to the noncalcareous sediments described by Scratch et al. (1984), is suggestive of a correlation with the combined Digdeguash and Flume Ridge Formations, as was suggested by Ludman (1975).

\section{Structure}

The area has experienced one phase of penetrative deformation and several phases of fracturing. Morrissy and Ruitenberg (1980) have identified an anticlinesyncline pair that trends $\mathrm{N} 20^{\circ} \mathrm{E}$ to $\mathrm{N} 50^{\circ} \mathrm{E}$, plunges $20^{\circ} \mathrm{SW}$, and has axial-planar cleavages that dip at $80^{\circ} \mathrm{NW}$ (Fig. 2). All of the intrusive rocks and vein and veinlet types at the mine crosscut these folds and are thus younger than the Acadian $D_{1}$ deformational phase.

Several fracture systems, now occupied by various types of dikes, veins, and veinlets, are developed in the metasediments and the monzogranite (Fig. 2). The quartz-feldspar porphyry dike system strikes $\mathrm{N} 15^{\circ}$ $\mathrm{W}$ and dips $71^{\circ} \mathrm{W}$. Similarly, the major trend of the quartz-scheelite veinlets is $\mathrm{N} 6^{\circ} \mathrm{E}, 57^{\circ} \mathrm{W}$; cogenetic veinlets of lesser magnitude are approximately oriented $\mathrm{N} 85^{\circ} \mathrm{W}, 76^{\circ} \mathrm{N}$. Another steeply dipping eastwest fracture set is occupied by the lamprophyric dikes. The stibnite-quartz veins, which postdate the W-Mo mineralization, occur in two orientations. The Hibbard vein strikes east-west and dips $35^{\circ} \mathrm{N}$; the Prout and Brunswick veins have similar orientations. 


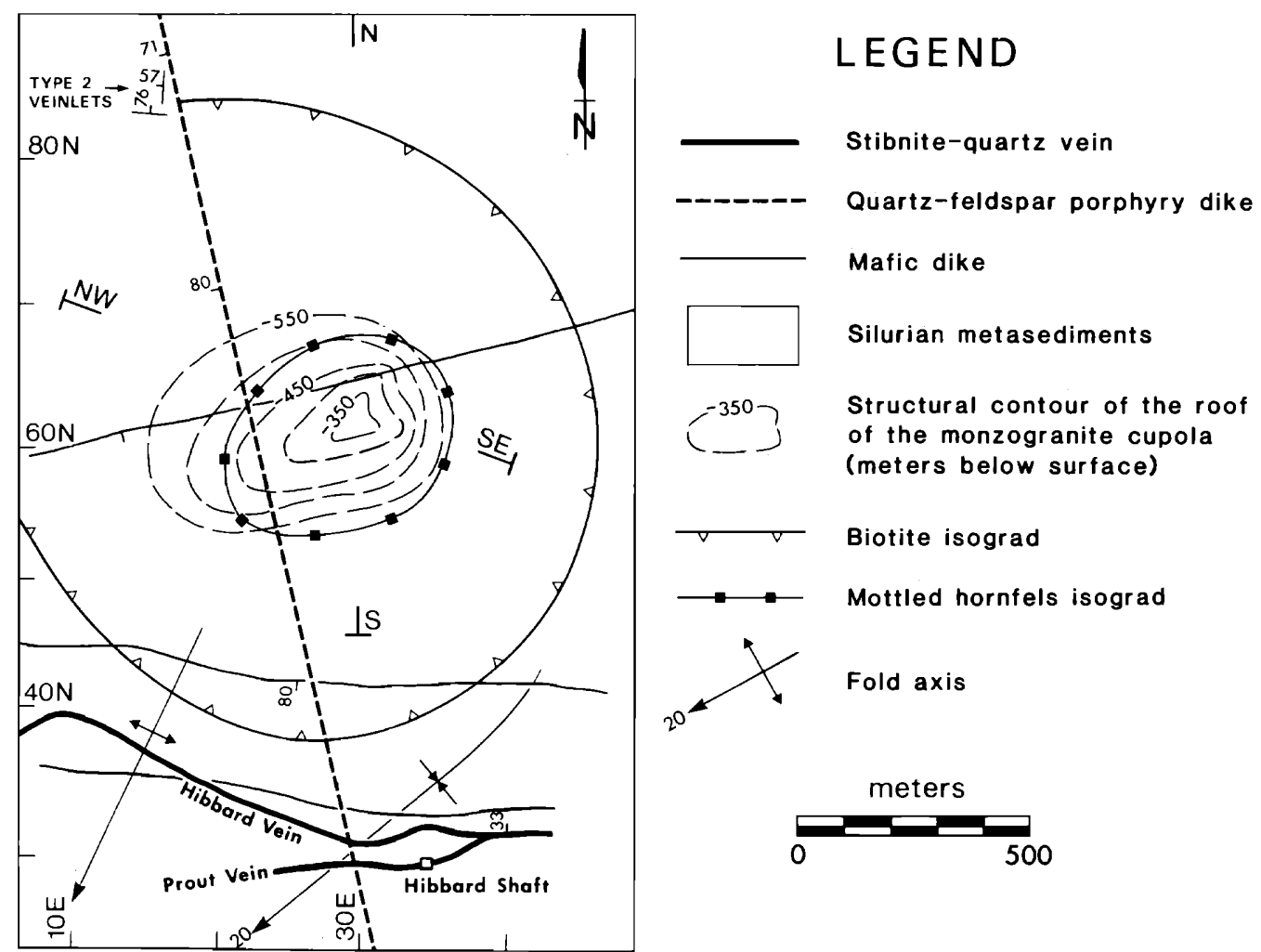

FIG. 2. Schematic geology of the Lake George mine site. The location of the monzogranite cupola is depicted as structural contours of its upper contact (in meters below the surface). Note the concentric disposition of the biotite and mottled hornfels isograds about the cupola (cf. fig. 4, Scratch et al., 1984). The locations of cross sections referred to in the text are indicated by "N-S," and "NW-SE." The single known outcrop of W-Mo veins is located at the northwest extremity of the map area.

The Lawrence vein, west of the mine workings, strikes north-south and dips $35^{\circ} \mathrm{E}$.

Scratch et al. (1984) claim that the contact metamorphic aureole associated with the granitoid cupola has been deformed by later folding. Petrographic examination of samples from the aureole, however, demonstrates that the metamorphism associated with the cupola was postkinematic; the metasediments within the aureole are hornfelsic. Moreover, the rigorously delineated metamorphic isograds, to be documented in a later section, are sensibly parallel to the intrusive contact and reveal no postmetamorphic structural complexities.

\section{Intrusive rocks}

The lamprophyric dikes average 0.5 to $4.0 \mathrm{~m}$ in thickness and are equigranular and medium grained. The primary mineralogy comprised ca. 30 percent ferroan pargasite, 20 percent biotite, 30 percent plagioclase, 10 percent feldspar, and 10 percent quartz, with trace amounts of apatite and opaques. The pargasite is variably replaced by actinolitic hornblende, the biotite by chlorite, the potassium feldspar by sericite, and the plagioclase by epidote, sericite, and carbonate.
Despite the lack of ferromagnesian phenocrysts, the Lake George rocks, poor in silica, alkali rich ( $\mathrm{K}$ $>\mathrm{Na}$ ), and with very high color indices, clearly have lamprophyric affinities (see Table 1). They probably conform to the spessartite division of the shoshonitic lamprophyre subclan of Rock (1977) and earlier workers, which is characteristically associated with postkinematic granitoid intrusions.

The quartz-feldspar porphyry dike system averages 3 to $5 \mathrm{~m}$ in thickness (Watson, 1981). The dike rocks are commonly porphyritic, but their texture ranges to seriate. They are typically composed of varying proportions of phenocrysts of partially resorbed quartz, sericitized strongly zoned plagioclase, and mildly chloritized biotite, in a groundmass of quartz, $\mathrm{K}$-feldspar, plagioclase, and biotite. Sphene is a common accessory. Two modal analyses of quartz-feldspar porphyry plot (Fig. 3) in the monzogranite field of the I.U.G.S. classification diagram (Streckeisen, 1976). Whole-rock chemical data (Table 1) for the quartz-feldspar porphyry dike plot (Fig. 4) on or below the plagioclase-biotite tie line on the $\mathrm{ACF}^{1}$ diagram of White and Chappell (1977). The oxidation

${ }^{1} \mathrm{~A}=\mathrm{Al}_{2} \mathrm{O}_{3}-\mathrm{Na}_{2} \mathrm{O}-\mathrm{K}_{2} \mathrm{O} ; \mathrm{C}=\mathrm{CaO} ; \mathrm{F}=\mathrm{MgO}+\mathrm{FeO}$. 
TABLE 1. Chemical Analyses and CIPW Norms for Igneous Rocks, Lake George (in wt \%)

\begin{tabular}{|c|c|c|c|}
\hline & $\begin{array}{l}\text { Monzo- } \\
\text { granite } \\
\text { cupola }\end{array}$ & $\begin{array}{c}\text { Quartz } \\
\text { feldspar } \\
\text { porphyry } \\
\text { dike }\end{array}$ & $\begin{array}{c}\text { Lampro- } \\
\text { phyric } \\
\text { dike }\end{array}$ \\
\hline $\mathrm{SiO}_{2}$ & 67.03 & 65.63 & 48.91 \\
\hline $\mathrm{TiO}_{2}$ & 0.63 & 0.43 & 1.39 \\
\hline $\mathrm{Al}_{2} \mathrm{O}_{3}$ & 14.50 & 15.21 & 11.75 \\
\hline $\mathrm{Fe}_{2} \mathrm{O}_{3}$ & 0.04 & 0.06 & 2.17 \\
\hline $\mathrm{FeO}$ & 3.00 & 2.76 & 6.12 \\
\hline $\mathrm{MnO}$ & 0.08 & 0.06 & 0.13 \\
\hline $\mathrm{MgO}$ & 1.32 & 1.16 & 11.86 \\
\hline $\mathrm{CaO}$ & 2.70 & 3.78 & 7.58 \\
\hline $\mathrm{Na}_{2} \mathrm{O}$ & 3.48 & 3.00 & 1.89 \\
\hline $\mathrm{K}_{2} \mathrm{O}$ & 3.79 & 2.87 & 3.81 \\
\hline $\mathrm{P}_{2} \mathrm{O}_{5}$ & 0.12 & 0.12 & 0.71 \\
\hline L.O.I. & 1.31 & 4.68 & 2.43 \\
\hline Total & 98.00 & 99.76 & 98.75 \\
\hline \multicolumn{4}{|l|}{ CIPW norms } \\
\hline Quartz & 23.56 & 27.07 & 0.00 \\
\hline Corundum & 0.05 & 0.62 & 0.00 \\
\hline Orthoclase & 23.16 & 17.82 & 23.36 \\
\hline Albite & 30.44 & 26.66 & 16.58 \\
\hline Anorthite & 13.05 & 18.88 & 12.79 \\
\hline Diopside & 0.00 & 0.00 & 17.06 \\
\hline Hypersthene & 8.14 & 7.50 & 2.91 \\
\hline Olivine & 0.00 & 0.00 & 0.00 \\
\hline Magnetite & 0.06 & 0.09 & 3.26 \\
\hline Ilmenite & 1.24 & 1.06 & 2.74 \\
\hline Apatite & 0.30 & 0.30 & 1.77 \\
\hline $\mathrm{Al}_{2} \mathrm{O}_{3}-\mathrm{Na}_{2} \mathrm{O}-\mathrm{K}_{2} \mathrm{O}$ & 0.43 & 0.51 & 0.15 \\
\hline $\mathrm{CaO}$ & 0.22 & 0.25 & 0.23 \\
\hline $\mathrm{MgO}+\mathrm{FeO}$ & 0.35 & 0.24 & 0.63 \\
\hline A/CNK & 0.98 & 1.02 & 0.56 \\
\hline Oxidation ratio & 0.01 & 0.02 & 0.24 \\
\hline
\end{tabular}

L.O.I. $=$ loss on ignition, $\mathrm{A} / \mathrm{CNK}=$ moles $\mathrm{Al}_{2} \mathrm{O}_{3} /[$ moles $(\mathrm{CaO}$ $\left.\left.+\mathrm{Na}_{2} \mathrm{O}+\mathrm{K}_{2} \mathrm{O}\right)\right]$

ratio $\left(\mathrm{Fe}^{+3} / \mathrm{Fe}^{+2}+\mathrm{Fe}^{+3}\right)$ is less than 0.5 . The $\mathrm{A} / \mathrm{CNK}$ ratio of the porphyry, 1.02 , indicates a modestly peraluminous composition but must be interpreted cautiously because of the high loss on ignition of this analysis.

The monzogranite (granodiorite porphyry of Scratch et al., 1984) cupola is elliptical in plan and flagrantly crosscuts the deformed Silurian strata. It does not crop out on surface or (to date) in the mine workings, but diamond drilling has intersected its apex approximately $500 \mathrm{~m}$ north of the Hibbard-Prout shaft at a depth of $435 \mathrm{~m}$ (Fig. 2). The monzogranite is typically fine to medium grained, seriate, and unfoliated. It consists of partially resorbed quartz, sericitized zoned plagioclase, partially chloritized biotite, and finer grained potassium feldspar. Hornblende, apatite, and sphene occur in trace amounts. Modal analyses of three samples plot in the monzogranite field and at the alkali feldspar-rich limit of the granodiorite field, in the I.U.G.S. classification diagram (Fig.

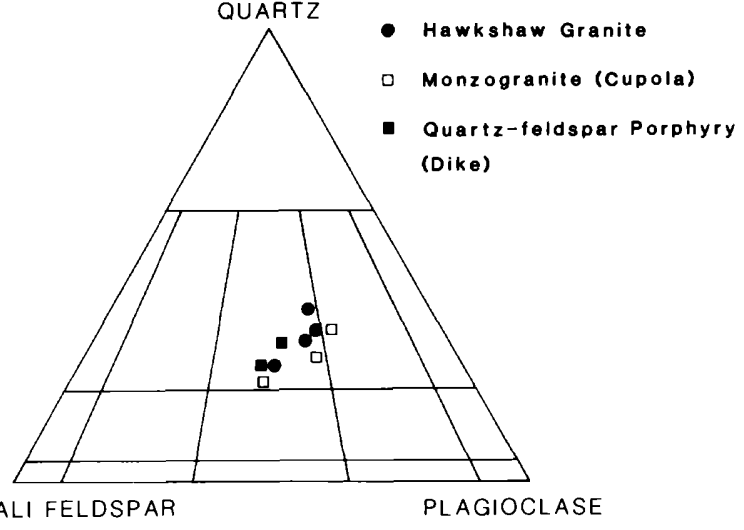

FIG. 3. Partial modal analyses of the Lake George monzogranite and quartz-feldspar porphyry, and of the Hawkshaw granite facies of the Pokiok batholith. Classification from Streckeisen (1976).

3). A whole-rock chemical analysis plots below the plagioclase-biotite tie line on the ACF diagram (Fig. 4) and yields an A/CNK ratio of 0.98 ; i.e., the rock is marginally metaluminous. The low oxidation ratio indicates an extremely reduced whole-rock composition.

Both the quartz-feldspar porphyry and monzogranite display chemical and mineralogical features transitional between those of I- and S-type granitoid rocks (White and Chappell, 1977). The nearby Hawkshaw monzogranite is compositionally similar (McCutcheon et al., 1981; Seal, 1984). These rocks conform to the ilmenite series of Ishihara (1977). Pitcher's (1983) "I (Caledonian)"-type granitoids may be generally analogous; these are also characteristically emplaced in the late, uplift stage of orogenesis.

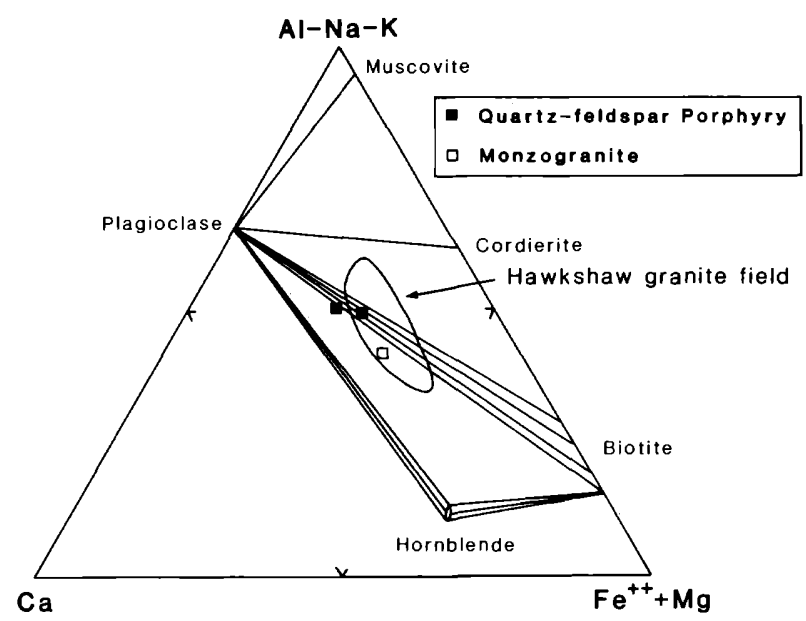

Fig. 4. ACF cation plot, after White and Chappell (1977), for the Lake George monzogranite and quartz-feldspar porphyry; the field of the Hawkshaw granite is also shown. 
(a)

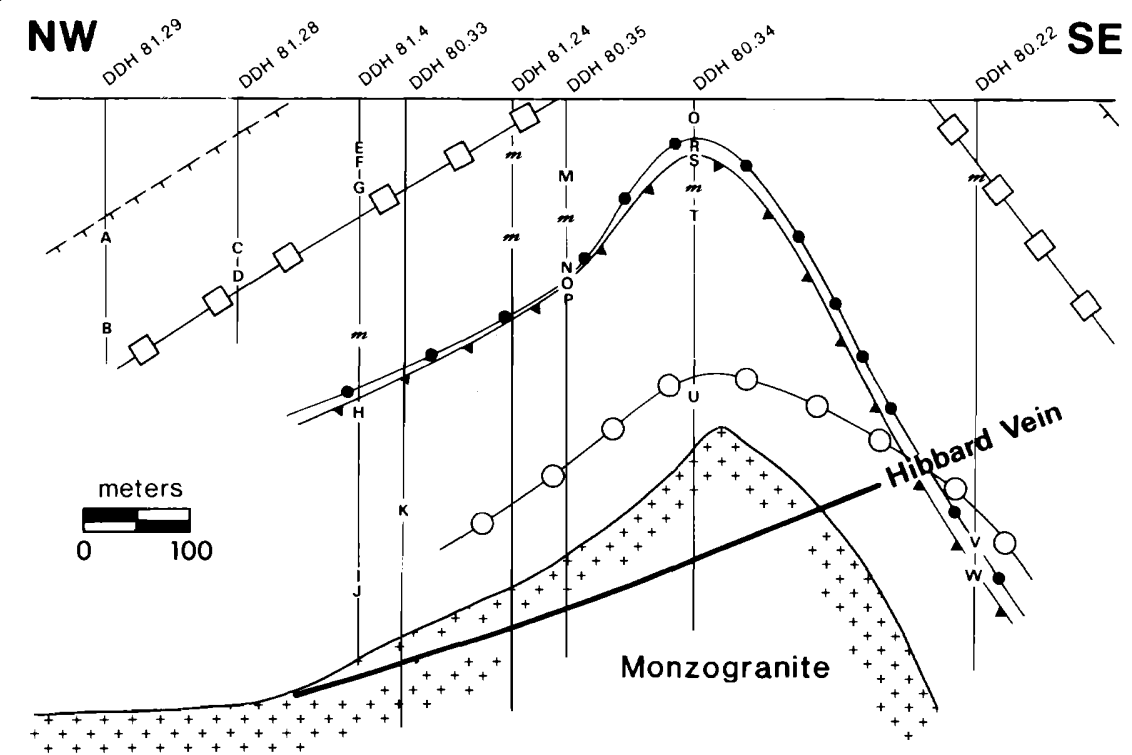

ISOGRADS

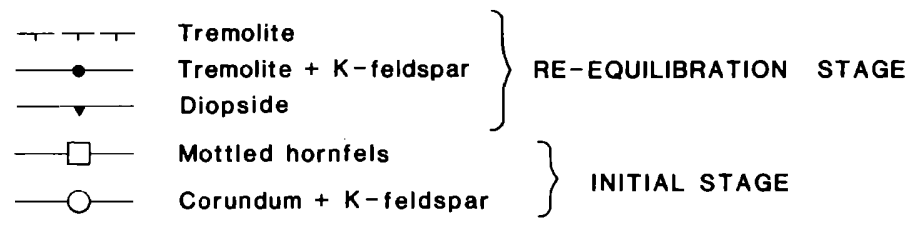

(b)

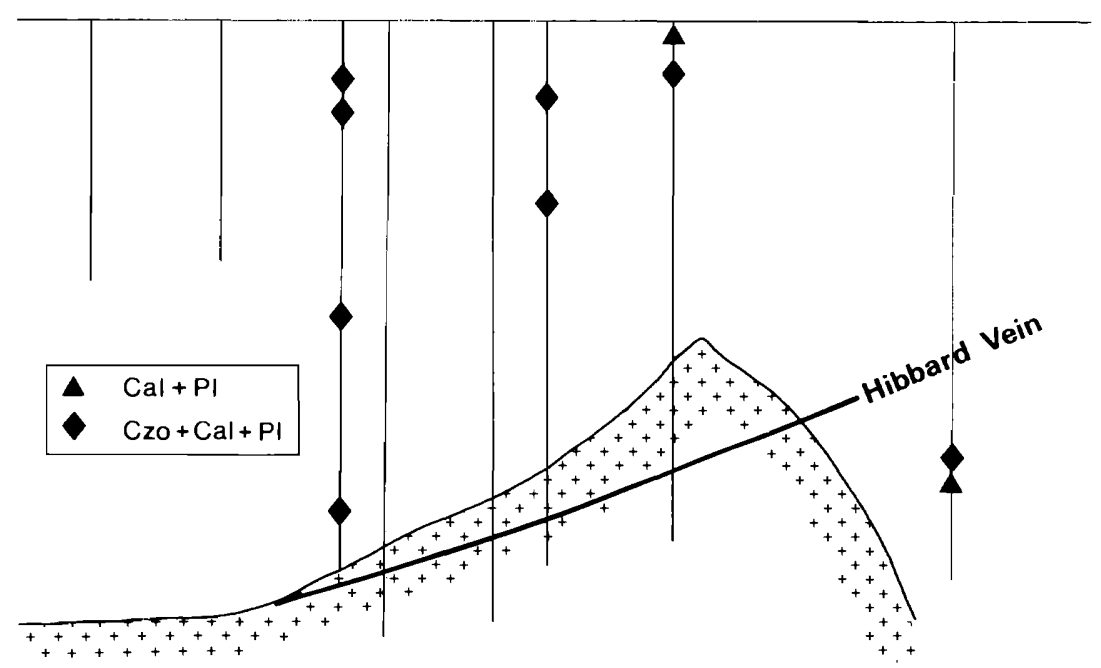

Fig. 5. Cross-sectional distribution of metamorphic mineral assemblages in the aureole of the monzogranite cupola. See Figure 2 for the location of the cross section (NW-SE). (a). Location of reaction isograds for the peak stage and the lower temperature reequilibration. The " $m$ "s indicate the observed locations of the mottled hornfelsic texture. The capital letters (A-W) correspond to the mineral assemblages in Table 2. (b). Observed locations of the fluid-buffering assemblage plagioclase + clinozoisite + calcite. 


\section{Metamorphism}

The Lake George area has been affected by three metamorphic events. The first was a regional lower greenschist facies metamorphism, associated with the Acadian $\mathrm{D}_{1}$ deformation, which produced the assemblage quartz + white mica + chlorite + plagioclase. The succeeding events were thermal metamorphisms associated with the emplacement of the Hawkshaw granite and the monzogranite cupola, which overprint the regional metamorphism but not one another, because of the separation of the intrusive bodies.

The metasediments adjacent to the cupola record the peak of thermal metamorphism and a later, lower temperature reequilibration (cf. Mathieson and Clark, 1984). The highest grades are recorded only in the pelitic hornfels, whereas the lower temperature reequilibration is evident in both pelitic and calc-silicate rocks. In rocks of pelitic composition, three prograde metamorphic isograds can be mapped, in order of increasing grade, on the basis of the first appearances of: (1) biotite, (2) a "mottled hornfelsic" texture, and (3) the assemblage K-feldspar + corundum. Surface outcrops are sparse at the mine site, thus delineation of isograds has been restricted to cross sections constrained by drill core (Fig. 5a). Mineral assemblages are presented in Table 2.

The transition from the lower greenschist facies, regionally metamorphosed pelites to the biotite zone is accompanied by a decrease in the modal proportion of chlorite and thus may be the result of the reaction:

$$
\text { chlorite }+ \text { phengite }=\text { biotite }+ \text { muscovite. }
$$

The succeeding isograd is mapped on the basis of the first appearance, in more aluminous layers, of mineral clots, rectangular and circular in cross section (Fig. 6a). These range up to $5 \mathrm{~mm}$ in diameter and are composed of muscovite with varying amounts of quartz, biotite, and $\mathrm{Mg}$ chlorite. The rectangular clots probably represent andalusite porphyroblasts that have been retrograded. The mineralogy of the circular clots prior to retrograding is less certain, but they may be relics of cordierite porphyroblasts. A reaction that could initially have produced the andalusite is:

quartz + muscovite

$$
=\mathrm{K} \text {-feldspar }+ \text { andalusite }+\mathrm{H}_{2} \mathrm{O} \text {. }
$$

One specimen was observed to contain the assemblage corundum $+\mathbf{K}$-feldspar in small domains where quartz is effectively isolated from the corundum by biotite and K-feldspar (Fig. 6b). The absence of muscovite in these domains suggests that this assemblage formed as the result of the reaction:

$$
\text { muscovite }=\text { corundum }+\mathrm{K} \text {-feldspar }+\mathrm{H}_{2} \mathrm{O} .
$$

\begin{tabular}{|c|c|c|c|c|c|c|c|c|c|c|c|}
\hline Sample ${ }^{1}$ & Quartz & Biotite & $\begin{array}{c}\text { Musco- } \\
\text { vite }\end{array}$ & $\begin{array}{c}\text { K-feld- } \\
\text { spar }\end{array}$ & $\begin{array}{c}\text { Corun- } \\
\text { dum }\end{array}$ & Calcite & Albite & Anorthite & $\begin{array}{l}\text { Clino- } \\
\text { zoisite }\end{array}$ & $\begin{array}{c}\text { Calcic } \\
\text { amphi- } \\
\text { bole }\end{array}$ & $\begin{array}{c}\text { Clinopy- } \\
\text { roxene }\end{array}$ \\
\hline $\mathbf{A}$ & $\mathrm{x}$ & $\mathrm{x}$ & & & & & & & & & \\
\hline B & $\mathrm{x}$ & $\mathrm{x}$ & & & & $\mathrm{x}$ & $\mathrm{x}$ & & & & \\
\hline C & $\mathrm{x}$ & $\mathrm{x}$ & & & & $\mathrm{x}$ & $\mathrm{x}$ & & & & \\
\hline D & $x$ & $\mathrm{x}$ & $\mathrm{x}$ & $\mathrm{x}$ & & $\mathrm{x}$ & & & & & \\
\hline $\mathbf{E}$ & $\mathrm{x}$ & & & & & & & $\mathrm{x}$ & $\mathrm{x}$ & $\mathrm{x}$ & \\
\hline $\mathrm{F}$ & $x$ & $\mathrm{x}$ & & & & & & & & $x$ & \\
\hline G & $x$ & & & & & $\mathrm{x}$ & & $\mathrm{x}$ & $\mathrm{x}$ & & \\
\hline $\mathbf{H}$ & $\mathbf{x}$ & & & & & $x$ & & $x$ & $\mathbf{x}$ & & $\mathrm{x}$ \\
\hline I & $\mathbf{x}$ & & & & & $\mathbf{x}$ & & $\mathrm{x}$ & $\mathrm{x}$ & & $\mathbf{x}$ \\
\hline $\mathbf{J}$ & $\mathbf{x}$ & $\mathrm{x}$ & & $\mathrm{x}$ & & & & & & $\mathrm{x}$ & \\
\hline $\mathbf{K}$ & $x$ & $\mathbf{x}$ & & $x$ & & & & & & $x$ & \\
\hline $\mathrm{L}$ & $\mathbf{x}$ & $\mathbf{x}$ & & $x$ & & & $x$ & & & & \\
\hline $\mathbf{M}$ & $\mathrm{x}$ & $\mathbf{x}$ & & & & $\mathrm{x}$ & & $x$ & $\mathrm{x}$ & $\mathbf{x}$ & $\mathrm{x}$ \\
\hline $\mathbf{N}$ & $\mathrm{x}$ & $\mathrm{x}$ & & & & $\mathrm{x}$ & & $\mathrm{x}$ & $\mathrm{x}$ & $\mathrm{x}$ & $\mathbf{x}$ \\
\hline O & $\mathrm{x}$ & & & & & $\mathbf{x}$ & & $\mathrm{x}$ & $\mathbf{x}$ & $\mathrm{x}$ & $\mathrm{x}$ \\
\hline $\mathbf{P}$ & $\mathrm{x}$ & $\mathrm{x}$ & & & & & & & & & \\
\hline Q & $\mathrm{x}$ & & & & & $\mathrm{x}$ & & $\mathrm{x}$ & & $\mathrm{x}$ & \\
\hline $\mathbf{R}$ & $\mathrm{x}$ & & & & & $\mathrm{x}$ & & $\mathrm{x}$ & $\mathbf{x}$ & $\mathrm{x}$ & $\mathrm{x}$ \\
\hline $\mathbf{S}$ & $\mathrm{x}$ & $\mathbf{x}$ & & & & & & $\mathrm{x}$ & & $\mathrm{x}$ & \\
\hline$T$ & $\mathbf{x}$ & $\mathbf{x}$ & & & & & & & & & \\
\hline $\mathbf{U}^{2}$ & $(\mathbf{x})$ & $\mathbf{x}$ & & $\mathbf{x}$ & $\mathbf{x}$ & & & & & & \\
\hline V & $\mathrm{x}$ & $\mathrm{x}$ & & $\mathrm{x}$ & & $\mathrm{x}$ & & $\mathrm{x}$ & $\mathrm{x}$ & $\mathbf{x}$ & \\
\hline $\mathbf{W}$ & $\mathbf{x}$ & & & & & $\mathrm{x}$ & & $\mathrm{x}$ & & $\mathrm{x}$ & $\mathbf{x}$ \\
\hline
\end{tabular}

TABLE 2. Mineral Assemblages of the Contact Aureole of the Lake George Monzogranite Cupola

${ }^{\mathrm{L}}$ For sample locations, see Figure 5a

${ }^{2}$ Quartz not in contact with corundum; see text 

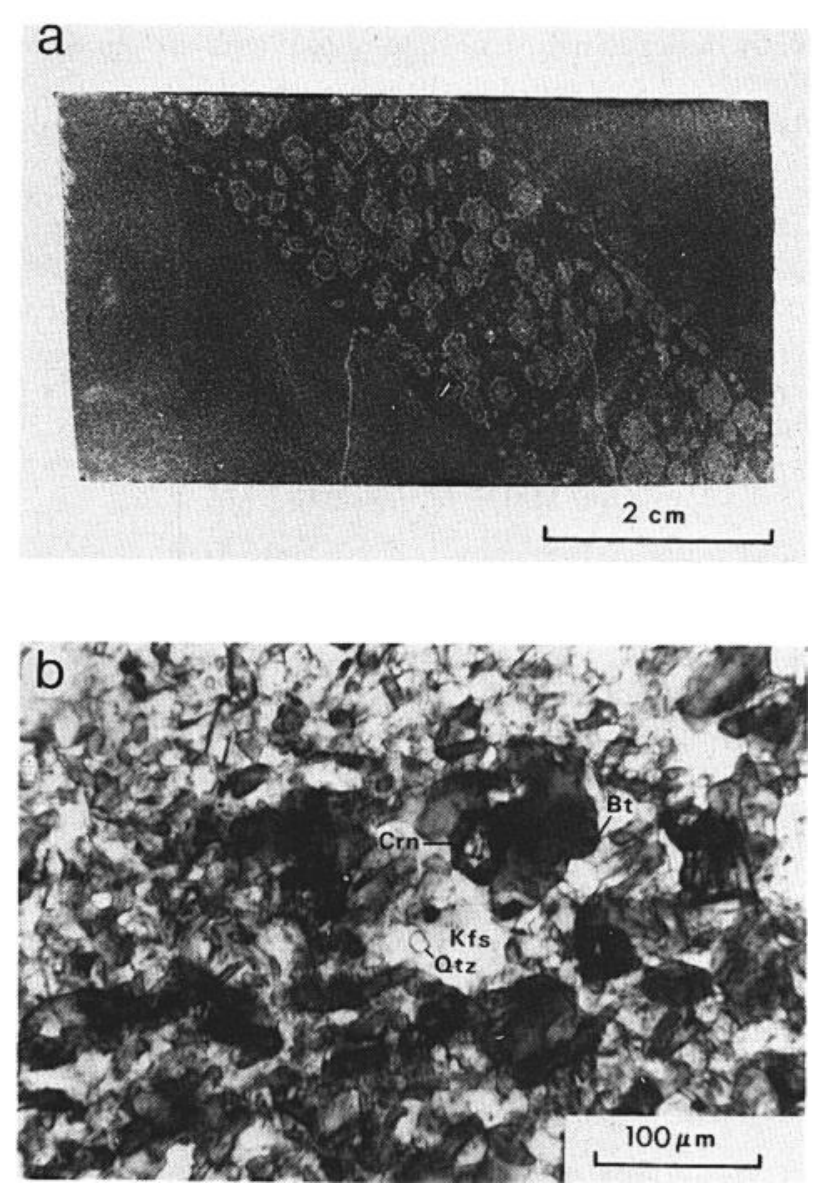

FIG. 6. Aspects of contact metamorphism of pelitic rocks in the aureole of the cupola. Note the hornfelsic textures. (a). Drill core sample of the mottled hornfels. The rectangular and circular mineral clots are considered to be retrograded andalusite and cordierite porphyroblasts, respectively (see text). (b). Photomicrograph (plane-polarized light) of the assemblage, corundum $(\mathrm{Crn})+$ potassium feldspar $(\mathrm{Kfs})+$ biotite $(\mathrm{Bt})$. Note that the quartz (Qtz) is isolated from the corundum by potassium feldspar.

The assemblage corundum $+\mathrm{K}$-feldspar places an upper pressure limit on contact metamorphism of 1.75 $\mathrm{kb}$, with temperatures exceeding $600^{\circ} \mathrm{C}$, assuming that the reaction occurred in the stability field of andalusite and that $\mathbf{P}_{\mathbf{H}_{2} \mathrm{O}}=\mathbf{P}_{\text {TOTAL }}$ (Fig. 7).

In rocks of marly composition, three isograds are mapped on the basis of the first appearances of: (1) tremolite, (2) the assemblage tremolite $+\mathrm{K}$-feldspar, and (3) diopside. A reaction corresponding to the first appearance of tremolite could be:

8 quartz +5 dolomite $+\mathrm{H}_{2} \mathrm{O}$

$$
=\text { tremolite }+3 \text { calcite }+7 \mathrm{CO}_{2} \text {. }
$$

The first appearance of tremolite $+\mathrm{K}$-feldspar is marked by the disappearance of calcite and/or biotite and is considered to reflect the reaction:

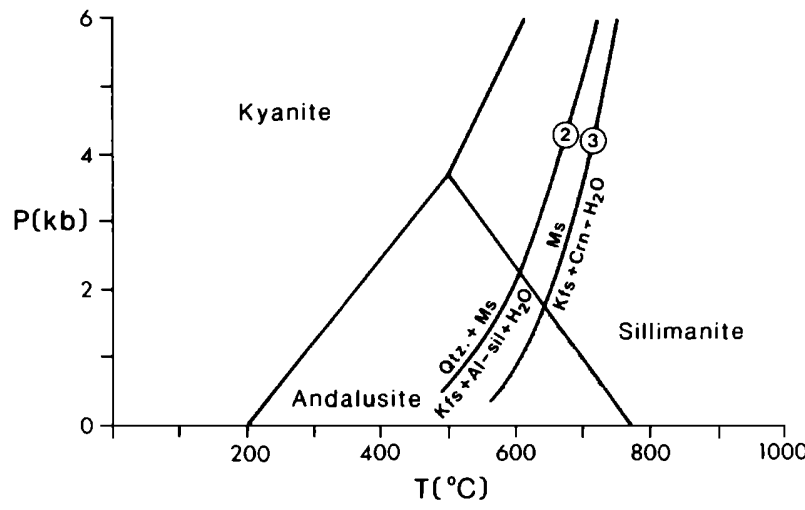

FIG. 7. Pressure-temperature relations for selected reactions in pelitic rock pertaining to contact metamorphism at Lake George. Aluminosilicate phase relations from Holdaway (1971); all other reactions were calculated using the thermochemical data of Helgeson et al. (1978) and the APL programs of D. M. Carmichael (pers. commun.).

$$
\begin{aligned}
& 24 \text { quartz }+6 \text { calcite }+5 \text { biotite } \\
& \quad=5 \mathrm{~K} \text {-feldspar }+3 \text { tremolite }+6 \mathrm{CO}_{2}+\mathrm{H}_{2} \mathrm{O} .
\end{aligned}
$$

The first appearance of diopside is marked by the disappearance of tremolite and/or calcite and is attributed to the reaction:

$$
\begin{aligned}
\text { quartz }+3 \text { calcite }+ & 2 \text { tremolite } \\
& =5 \text { diopside }+3 \mathrm{CO}_{2}+\mathrm{H}_{2} \mathrm{O} .
\end{aligned}
$$

Furthermore, much of the calc-silicate hornfels discussed above contains the assemblage clinozoisite + plagioclase + calcite (Fig. $5 b$ ), reflecting the reaction:

$$
\begin{aligned}
& 2 \text { clinozoisite }+\mathrm{CO}_{2} \\
& =3 \text { anorthite }+ \text { calcite }+\mathrm{H}_{2} \mathrm{O} .
\end{aligned}
$$

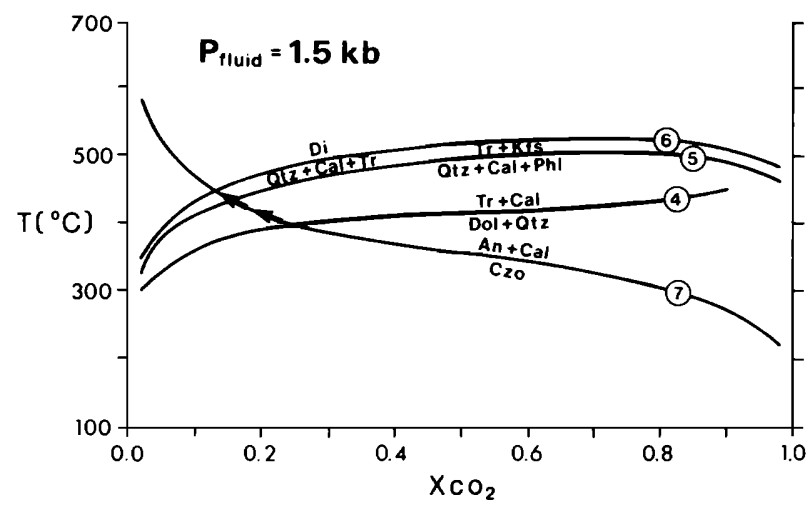

FIG. 8. Temperature- $\mathrm{X}_{\mathrm{CO}_{2}}$ diagram for calc-silicate reactions pertaining to contact metamorphism at Lake George. Calculated as in Figure 7. Arrows indicate the inferred metamorphic fluid composition accompanying the lower temperature reequilibration (see text). 
Thus, the metamorphic fluid composition associated with these stabilities was mineralogically buffered with respect to $\mathrm{H}_{2} \mathrm{O}$ and $\mathrm{CO}_{2}$ (Greenwood, 1975) and became increasingly water rich with increasing grade (Fig. 8).

Calculated shifts in calc-silicate stabilities, using electron microprobe mineral composition data (Seal, 1984) and assuming a confining pressure of $1.5 \mathrm{~kb}$ (consistent with the constraints placed by the pelitic assemblages), indicate that the contact metamorphism of the calc-silicates occurred at temperatures of $350^{\circ}$ to $450^{\circ} \mathrm{C}$ and that the $\mathrm{X}_{\mathrm{CO}_{2}}$ of the fluids ranged from 0.25 to 0.10 (Fig. 8). These temperatures are consistent not with those estimated for the peak conditions recorded in the pelitic hornfels but with the retrograde assemblages of the mottled hornfels porphyroblasts (cf. Fig. 7); they thus verify the occurrence of a lower temperature reequilibration. The mineralog- ically buffered nature of the fluids in equilibrium with the calc-silicate hornfels strongly suggests that contact metamorphism had ceased prior to the onset of hydrothermal activity.

We infer that the pelitic to marly compositions of the host rocks exerted a significant control on the mineralization style at Lake George, in that the lack of marble precluded significant exoskarn formation and that the hornfelsic nature of the host rocks was conducive to the development of the stockwork fractures (cf. Williams-Jones, 1982).

\section{Tungsten-Molybdenum Mineralization}

\section{Classification and temporal relations}

The tungsten- and/or molybdenum-bearing veinlets at Lake George can be divided into three groups on the basis of mineralogy and associated alteration, as
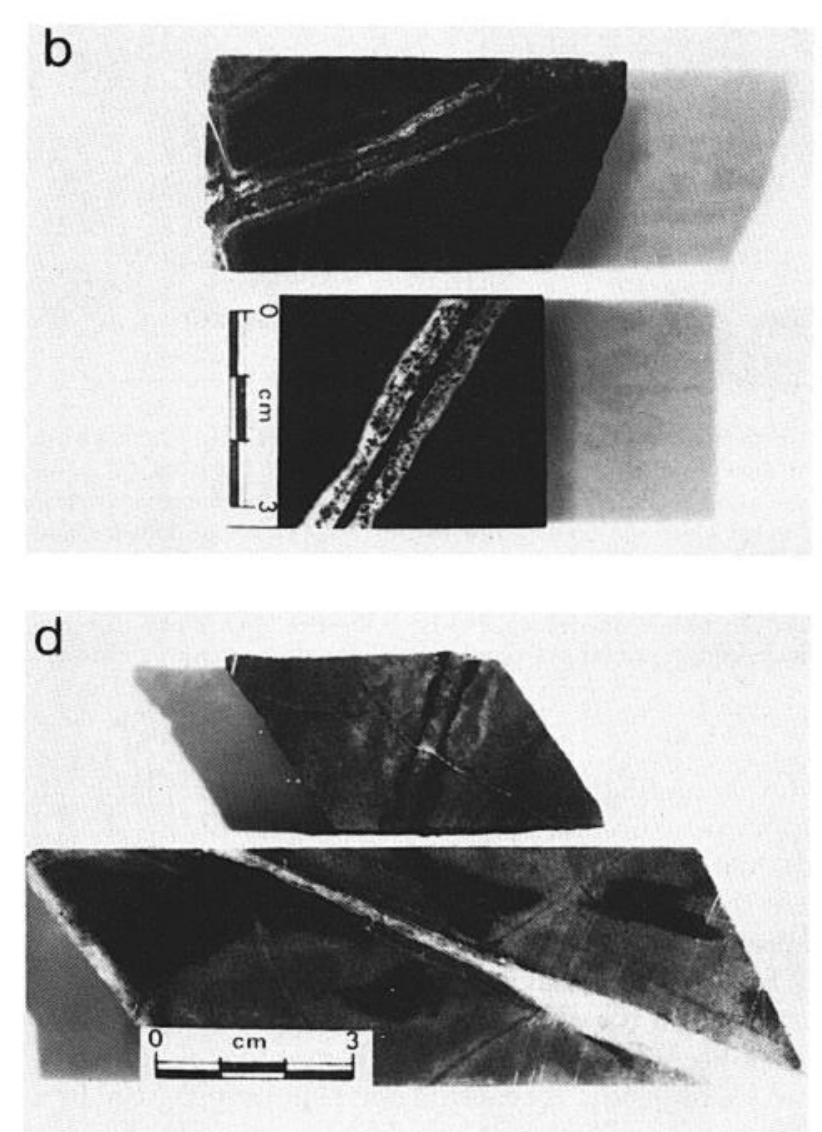
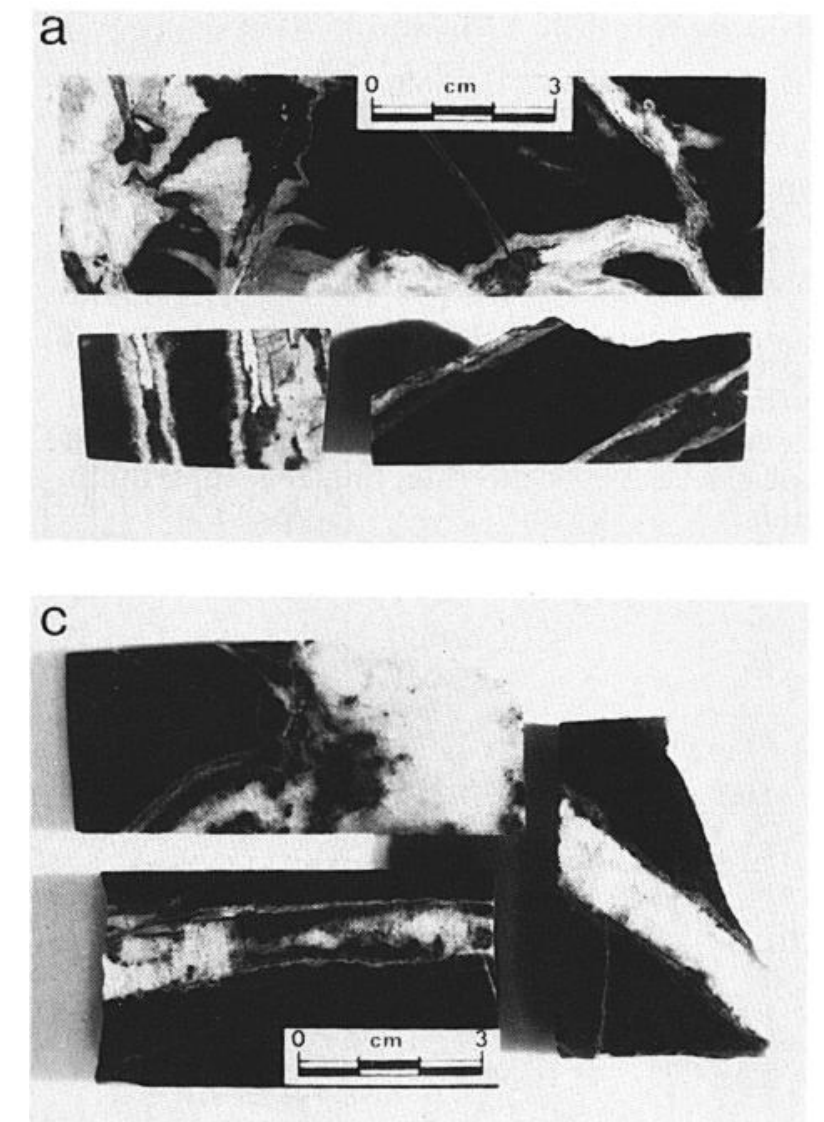

FIG. 9. Megascopic aspects of type 1 veinlets. (a). Calc-silicate-dominated veinlets hosted by pelitic hornfels (dark gray). Ca metasomatic alteration envelopes (light gray) occur adjacent to the veinlets. White areas in the centers of veinlets comprise wollastonite, calcite, and quartz, whereas the medium gray centers consist of clinopyroxene and garnet. The anastomosing nature of the veinlets is characteristic. (b). Calcic amphibole-bearing veinlets hosted by pelitic hornfels (dark gray). Ca metasomatic alteration envelopes (light gray) are evident. (c). Quartz-dominated veinlets hosted by pelitic hornfels (dark gray). Note alteration envelopes. (d). Quartz-dominated veinlets hosted by calc-silicate hornfels (medium gray) with minor pelitic hornfels (dark gray). Note alteration envelopes. 
well as relative age. The earliest group, type 1 , comprises scheelite- and molybdenite-bearing calc-silicate quartz veinlets, with alteration envelopes produced by both calcium and hydrogen metasomatism of the wall rocks. Although veinlets of this type have not definitely been observed within the monzogranite, they clearly postdated its associated thermal metamorphism. They are also cut by lamprophyric and quartz-feldspar porphyry dikes. The second group, type 2 , is characterized by scheelite- and molybdenite-bearing veinlets, with weak and narrow alteration envelopes, which developed subsequent to the emplacement of the porphyry dikes. The third group, type 3 , consists of prehnite, molybdenite, and quartz and formed subsequent to type 2 mineralization but prior to the economic stibnite-quartz veins.

Two hydrothermal muscovites associated with the second stage of W-Mo mineralization yielded latest
Silurian K-Ar ages of $411 \pm 8$ and $413 \pm 8$ m.y. (Seal et al., 1985a).

\section{Type 1 veinlets}

Petrography: Type 1 veinlets, $5 \mathrm{~mm}$ to $5 \mathrm{~cm}$ in width, have been divided into calc-silicate-dominated and quartz-dominated varieties (Fig. 9a-d). Typically, individual veinlets and their altered wall-rock envelopes show a distinct chemical zonation in calcium content.

The calc-silicate-dominated bodies contain varying amounts of calcic clinopyroxene, granditic garnet, wollastonite, calcic amphibole, calcite, and quartz. Quartz and calcite are ubiquitous, but minor, in the cores of these veinlets. Wollastonite and garnet are restricted to the cores of calc-silicate-dominated veinlets and are commonly associated with lesser amounts of clinopyroxene and calcite (Fig. 10a and
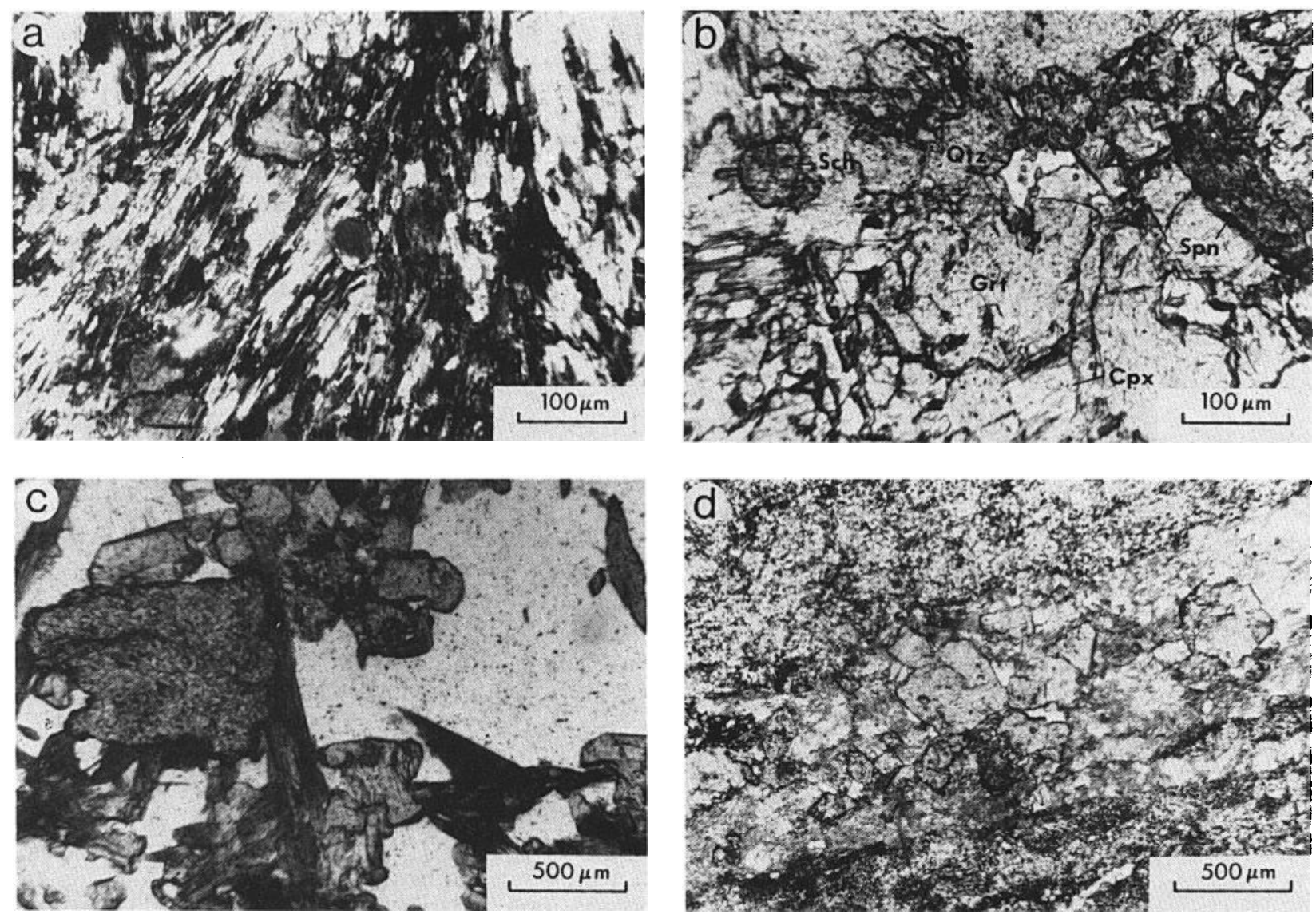

FIG. 10. Microscopic aspects of type 1 veinlets. (a). Felted wollastonite grains with equant, anhedral, clinopyroxene grains from the core of calc-silicate-dominated veinlet (cross-polarized light). (b). Anhedral grains of garnet (Grt), clinopyroxene (Cpx), quartz (Qtz), sphene (Spn), and scheelite (Sch) from the core of a calc-silicate-dominated veinlet (plane-polarized light). (c). Subhedral, equant scheelite (mottled gray) with acicular calcic amphibole (dark gray) and quartz (white) from the margin of a quartz-dominated veinlet (plane-polarized light). (d). Highly metasomatised hornfels (upper left, lower right) hosting a calc-silicate-dominated veinlet consisting of scheelite (light gray, high relief), calcic amphibole (medium gray), and quartz (white) (plane-polarized light). 
b). Clinopyroxene is most abundant peripheral to the wollastonite, garnet, or calcite-quartz cores. In the absence of the latter minerals, clinopyroxene is commonly the dominant calc-silicate in the cores of veinlets. Calcic amphibole is locally present in calc-silicate-dominated veinlets as acicular grains exhibiting strong brownish-green to bluish-green pleochroism and apparently replacing clinopyroxene. Clinozoisite, sphene, and apatite occur in minor amounts. The common ore minerals are scheelite, molybdenite, and pyrrhotite, all of which occur most abundantly in the Ca-rich cores of the veinlets (Fig. $10 \mathrm{~b}$ and d).

The quartz-dominated veinlets consist of quartz with lesser amounts of granditic garnet, calcic clinopyroxene, calcic amphibole, plagioclase, clinozoisite, calcite, and sphene. Clinozoisite and calcite are commonly associated with the garnet, suggesting that the former are the result of garnet breakdown. Calcic amphibole is present in two morphologies: acicular grains, exhibiting strong brownish-green to bluishgreen pleochroism (Fig. 10c) and commonly replacing clinopyroxene, as discussed above; and subequant to bladed grains, exhibiting pale green pleochroism and texturally appearing to be of primary origin. Ore minerals in quartz-dominated veinlets include

- Calc-silicate dominated veins

- Quartz dominated veins

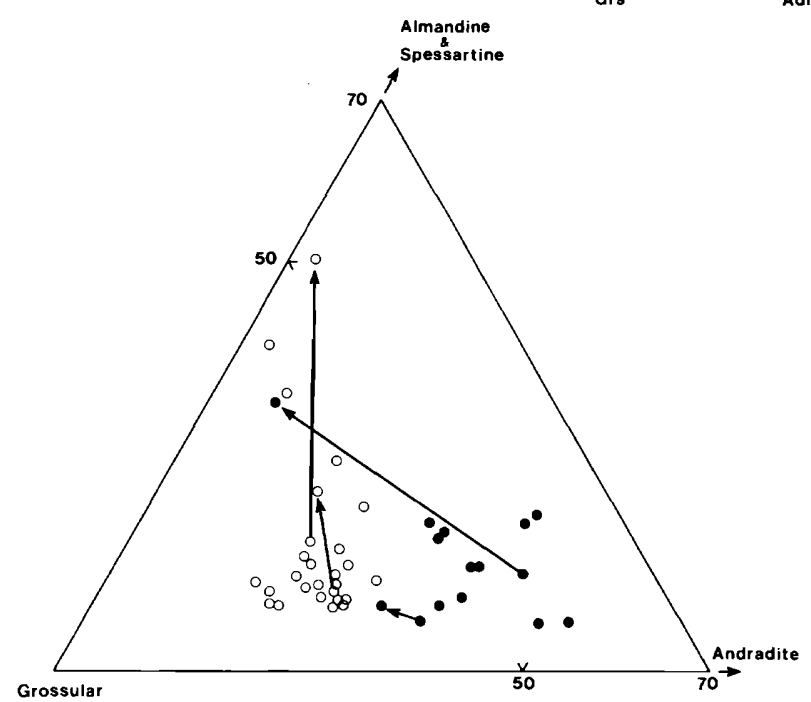

FTG. 11. Compositions of hydrothermal garnets from type 1 veinlets. Arrows indicate compositional zoning from cores to rims of grains. End-member formulas are: grossular, $\mathrm{Ca}_{3} \mathrm{Al}_{2} \mathrm{Si}_{3} \mathrm{O}_{12}$; andradite, $\mathrm{Ca}_{3} \mathrm{Fe}_{2} \mathrm{Si}_{3} \mathrm{O}_{12}$; spessartine, $\mathrm{Mn}_{3} \mathrm{Al}_{2} \mathrm{Si}_{3} \mathrm{O}_{12}$; and almandine, $\mathrm{Fe}_{3} \mathrm{Al}_{2} \mathrm{Si}_{3} \mathrm{O}_{12}$.

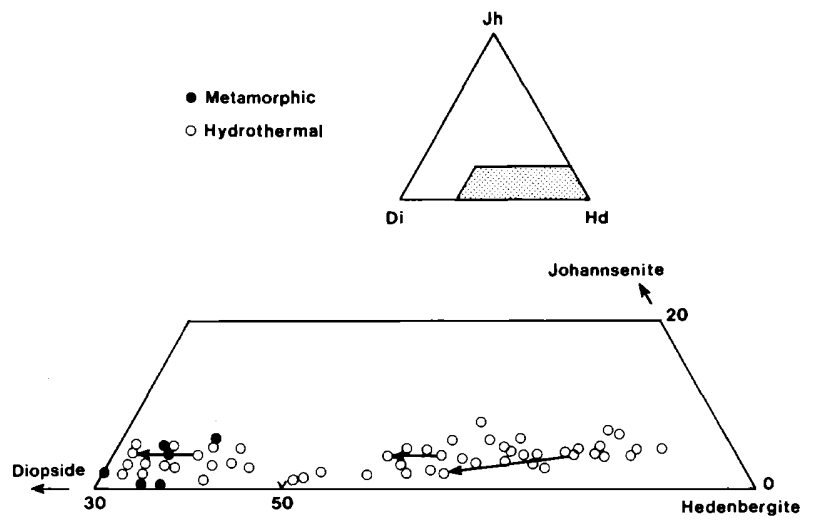

Fig. 12. Compositions of hydrothermal and metamorphic clinopyroxenes from type 1 veinlets and the calc-silicate hornfels, respectively. Arrows indicate compositional zoning from cores to rims of grains. Note limited compositional variation of metamorphic compared to hydrothermal pyroxenes. End-member formulas are: diopside, $\mathrm{CaMgSi}_{2} \mathrm{O}_{6}$; hedenbergite, $\mathrm{CaFeSi}_{2} \mathrm{O}_{6}$; and johannsenite, $\mathrm{CaMnSi}_{2} \mathrm{O}_{6}$.

scheelite, molybdenite, pyrite, pyrrhotite, and trace chalcopyrite.

Compositions of calc-silicate minerals: Garnets in type 1 veinlets are generally Ca rich, but some contain appreciable ferrous iron. Grossular is normally the major component, but compositions range to 54 mole percent andradite, 40 mole percent almandine, or 12 mole percent spessartine (Fig, 11). Neither the pyrope nor uvarovite component exceeds 1 mole percent. The garnets in the calc-silicate-dominated veinlets are generally more grossular rich than those in the quartz-dominated veinlets. Grains show a marked compositional zoning from grossular-rich cores to more almandine- and spessartine-rich rims (Fig. 11). Shimazaki (1977), Dick and Hodgson (1982), and Newberry (1983) document similar trends in garnets in scheelite-bearing skarns. The garnets in the quartzdominated veinlets show marked compositional zoning from andradite-rich cores to grossular-, almandine-, and spessartine-rich rims.

The hydrothermal pyroxenes range in composition from salite to hedenbergite (Fig. 12). The johannsenite content does not exceed 9 mole percent. Compositional zoning, though not common, is from hedenbergitic or ferrosalitic cores to more diopsidic rims (Fig. 12). Metamorphic pyroxenes, situated away from the influence of hydrothermal activity, overlap in composition with the field defined by the hydrothermal pyroxenes, but they lack the range exhibited by the latter (Fig. 12). Similar relative compositional variations for metamorphic and metasomatic pyroxenes associated with tungsten skarns in the western United States are reported by Einaudi et al. (1981).

The two amphibole types (strongly vs. weakly pleochroic), described earlier, are compositionally 


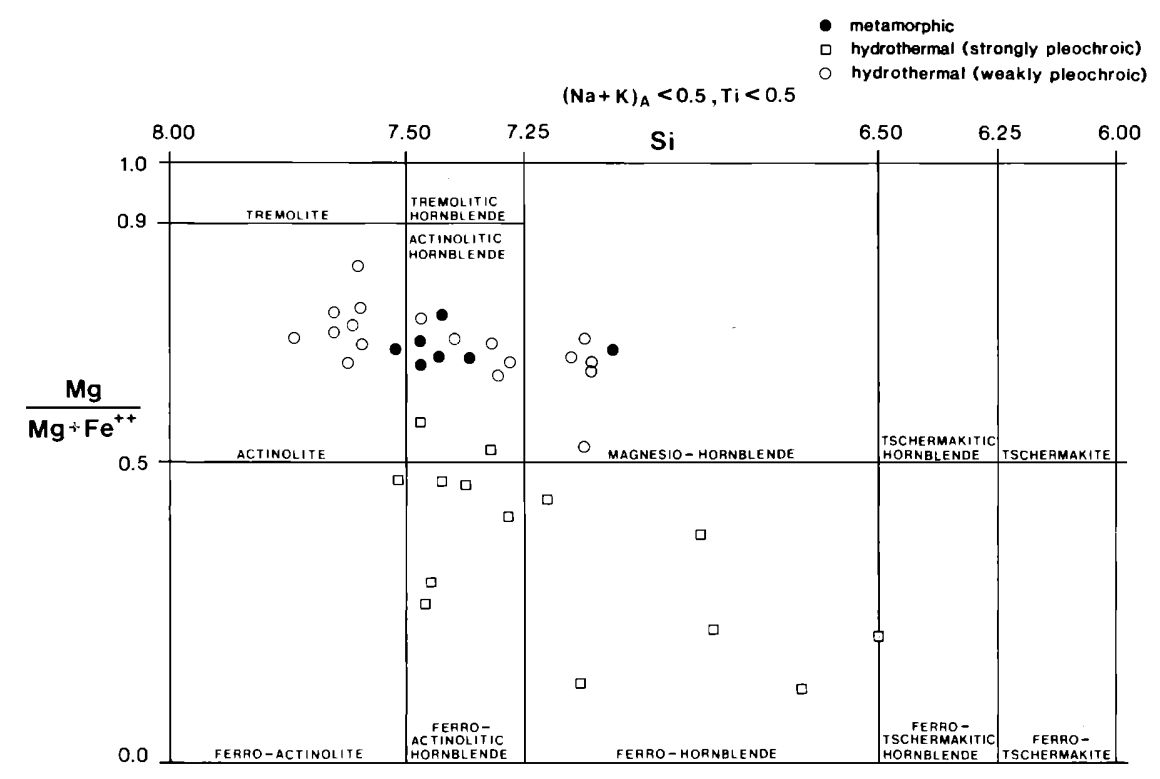

FIG. 13. Compositions of hydrothermal and metamorphic calcic amphiboles from type 1 veinlets and the calc-silicate hornfels, respectively. Note limited compositional variation of metamorphic compared to hydrothermal amphiboles. Classification from Leake (1978).

distinct. Both have low amounts of $\mathrm{Na}, \mathrm{K}$, and $\mathrm{Ti}$, but the weakly pleochroic variety is generally more magnesian and less aluminous than the strongly pleochroic (Fig. 13). The composition of the former ranges from actinolitic hornblende to magnesiohornblende, whereas the strongly pleochroic amphiboles generally range from ferroactinolitic hornblende to ferrohornblende (nomenclature of Leake, 1978). Dick and Hodgson (1982) report similar amphibole compositions from tungsten skarns in the Yukon and Northwest Territories, Canada. As with the pyroxenes, the metamorphic amphiboles lack the wide range of composition exhibited by their hydrothermal counterparts (Fig. 13).

Alteration: The common denominator which links all of the veinlets described above is the ubiquitous, but small-scale, calcium metasomatism of the wall rocks (Fig. 10d). This is commonly accompanied by hydrogen metasomatism. Alteration is apparent in rocks of marly composition, but it is most intensely developed in pelitic hosts. In both rock types, the metasomatism manifests itself in the systematic calcification of ferromagnesian and aluminous minerals. The alteration of rutile and ilmenite to produce sphene is ubiquitous. The alteration envelopes rarely extend more than $5 \mathrm{~mm}$ into the host rock.

In rocks of pelitic composition, the chemical zonation associated with alteration and mineralization is most intensely developed near the monzogranite cupola contact. One example with a well-developed zonation, ranging from unaltered wall rock, through progressively altered wall rock, and finally through a zoned veinlet-filling assemblage is depicted on an ACF oxide plot (Fig. 14a). A second example exhibits more regular chemical trends (Fig. 14b) than does the above. The absence of pyroxene and the presence of calcic amphibole in the second example probably reflects a lower temperature of formation due to the more distal setting of this veinlet relative to the cupola. In both of these examples, scheelite and molybdenite occur in the cores of the veinlets, associated with the most calcic assemblages.

From the ACF oxide plots (Fig. 14a and b), it is apparent that these mineralogical changes represent a relative enrichment of calcium with respect to ferrous iron, magnesium, and aluminum. From Figure $14 \mathrm{a}$, it is apparent that the transition from altered wall rock to veinlet was accompanied by a decrease in the proportion of aluminum; ferrous iron and magnesium were initially enriched but were depleted toward the core of the veinlet. This mineralogical and chemical zonation, culminating with the most Ca-rich assemblages at the cores of the veinlets, probably reflects the addition of ferrous iron and magnesium, derived from the wall rocks, to a Ca-rich hydrothermal fluid. The marked drop in the aluminum content across the host rock-veinlet contact is probably due to the low solubility of aluminum in hydrothermal solutions (Helgeson, 1969).

Calcium and hydrogen metasomatism of rocks of marly composition produced trends similar to those documented above for pelitic rocks, but predictably, the changes were not as pronounced. The alteration and veinlet-filling assemblages of two samples hosted 

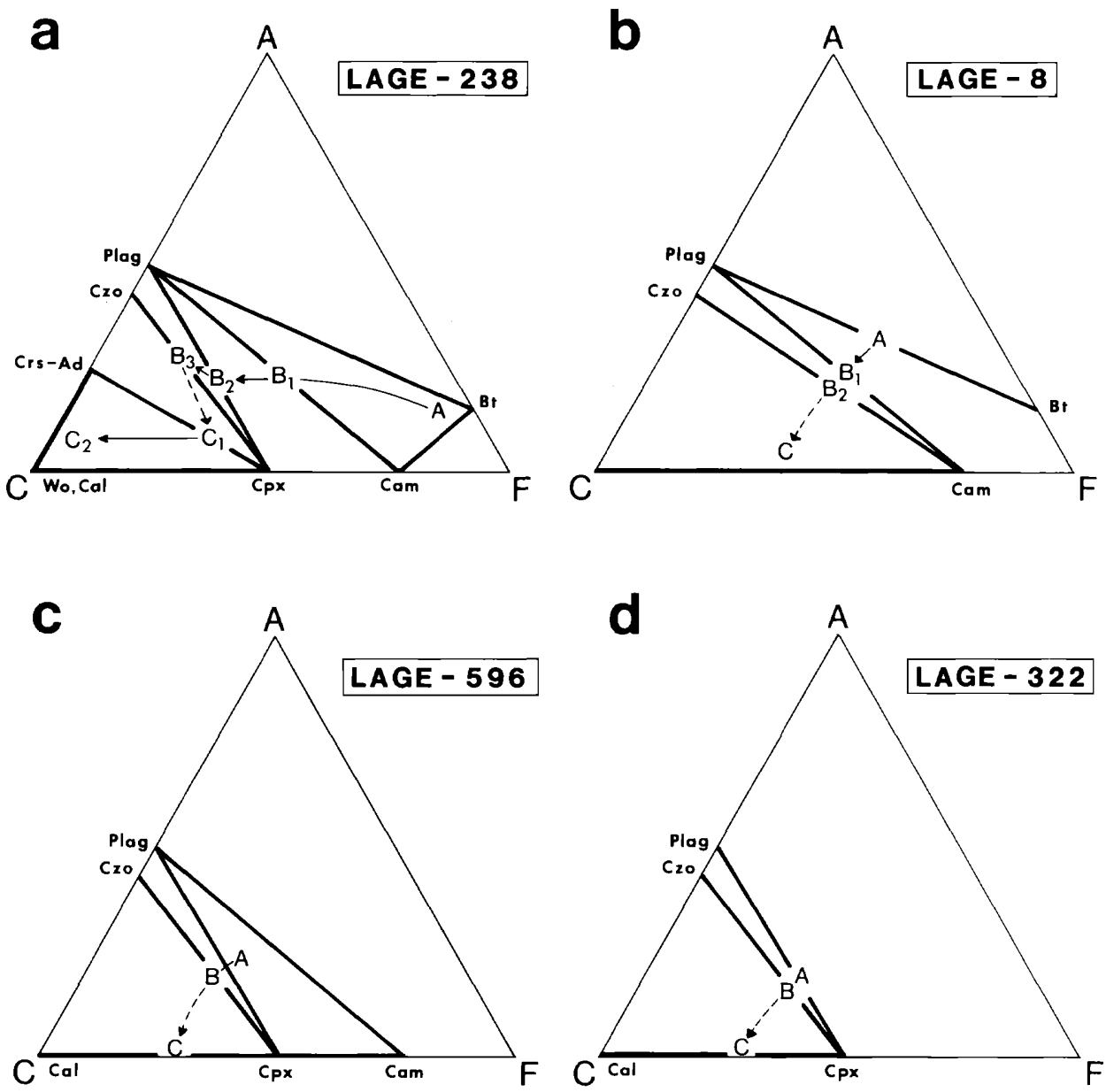

FIG. 14. ACF oxide plots of Type 1 alteration and veinlet assemblages. The direction of the arrows indicates the transition from unaltered wall rock (A), through successive zones of wall-rock alteration $\left(B\right.$, or $B_{1}, B_{2}$, and $B_{3}$, respectively), to veinlet zones $\left(C\right.$, or $C_{1}$ and $\left.C_{2}\right)$. Broken arrows mark the transition from wall-rock assemblages to veinlet assemblages. Mineral proportions were estimated visually. Abbreviations: Plag = plagioclase; $\mathrm{Czo}=$ clinozoisite; $\mathrm{Grs-Ad}=$ grossular-andradite; $\mathrm{Cal}=$ calcite; Wo $=$ wollastonite $; \mathbf{C p x}=$ clinopyroxene $; \mathrm{Cam}=$ calcic amphibole; $\mathrm{Bt}=$ biotite; $\mathrm{A}=\mathrm{Al}_{2} \mathrm{O}_{3}-\mathrm{Na}_{2} \mathrm{O}-\mathrm{K}_{2} \mathrm{O} ; \mathrm{C}$ $=\mathrm{CaO}$; and $\mathrm{F}=\mathrm{MgO}+\mathrm{FeO}$. (a). Pelite-hosted veinlet (sample LAGE-238). The relative proportion of $\mathrm{Al}_{2} \mathrm{O}_{3}$ decreases abruptly upon entering veinlet. (b). Pelite-hosted veinlet (sample LAGE-8). Note regularity of trend. (c). Calc-silicate-hosted veinlet (sample LAGE-596). The less extensive zonation, compared to that in samples LAGE-238 and LAGE-8, is due to the more calcic wall rock. (d). Calcsilicate-hosted veinlet (sample LAGE-322). The lack of calcic amphibole in the unaltered wall rock indicates a high metamorphic grade relative to sample LAGE-596.

by calc-silicate wall rocks are depicted in Figure 14c and $d$. The lack of calcic amphibole in the unaltered wall-rock assemblage in the second example (Fig. 14d) is due to its higher grade of contact metamorphism prior to mineralization. From ACF oxide plots (Fig. $14 \mathrm{c}$ and $\mathrm{d}$ ), it is evident that the mineralogical changes also represent an inward increase in calcium relative to aluminum, ferrous iron, and magnesium.

An important aspect of this alteration-mineralization process not immediately evident from the ACF plots (Fig. 14a-d) is that calcium enrichment of both wall-rock types was accompanied by hydrogen meta- somatism, involving the conversion of plagioclase to clinozoisite.

Areal distribution: Type 1 mineralization occurs close to the apex of the cupola (Fig. 15) and comprises veinlets that are both concordant and discordant with respect to bedding (Fig. $9 a-d)$. The veinlets are exposed in drill core and in recent (1985) underground development. Their orientation bears no relationship to regional structures. We thus infer that these fractures resulted from hydraulic fracturing associated with the evolution of a vapor phase from the monzogranite (Burnham, 1979). 


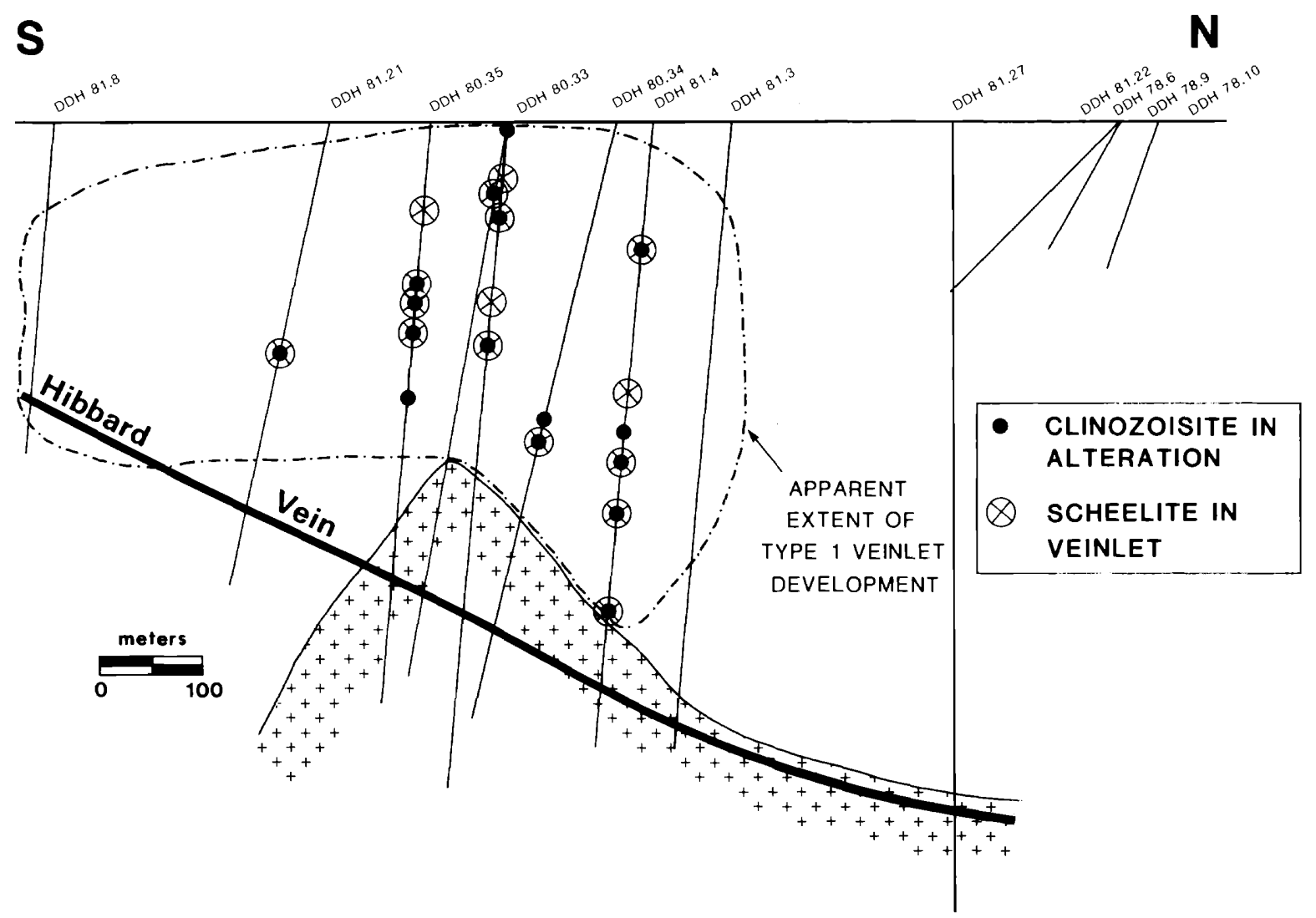

Fig. 15. Cross section depicting the distributions of scheelite in type 1 veinlets and clinozoisite in type 1 alteration envelopes. The close correspondence of the occurrence of these two minerals supports the hypothesis that scheelite deposition was related to hydrogen metasomatism of the wall rocks (see text). The dashed line indicates the known extent of type 1 mineralization. See Figure 2 for the location of the cross section.

The distributions of specific veinlet-filling and alteration calc-silicate minerals are broadly concentric to the monzogranite-metasediment contact. In general, the anhydrous minerals, garnet and clinopyroxene, occur closer to the monzogranite than their hydrous counterparts, clinozoisite and calcic amphibole. Scheelite and molybdenite are also more abundant in veinlets proximal to the cupola.

Fluid inclusions: A limited number (12) of fluid inclusions in type 1 veinlets were studied by nondestructive heating and freezing techniques using a Chaixmeca combination heating and cooling stage. Details of sample locations and of microthermometric data are recorded in Seal (1984). No evidence was found for boiling at the time of entrapment. The majority of the inclusions consisted of two phases (brine + vapor), but several were found to contain three (brine $+\mathrm{CO}_{2}$ liquid + vapor).

Salinities range from 4.1 to 17.5 equiv wt percent $\mathrm{NaCl}$ (avg 10.0 equiv wt \%). Many first-melting observations were between $-35^{\circ}$ and $-52^{\circ} \mathrm{C}$, suggesting that $\mathrm{CaCl}_{2}$ is one of the dissolved species (Craw- ford, 1981) and consistent with the Ca metasomatic alteration associated with these veinlets. Liquid and vapor $\mathrm{CO}_{2}$ were observed in several of these inclusions, estimated at less than 5 mole percent and usually less than 3 mole percent.

Temperatures of homogenization $\left(\mathrm{T}_{\mathrm{h}}\right)$ and decrepitation $\left(\mathrm{T}_{\mathrm{d}}\right)$ ranged from $178^{\circ}$ to $384^{\circ} \mathrm{C}$. Correction for a confining pressure (Potter, 1977) of $1.3 \mathrm{~kb}$ (on the basis of metamorphic arguments advanced earlier and on fluid inclusion evidence presented in a later section) yields temperatures in the range of $288^{\circ}$ to $559^{\circ} \mathrm{C}$.

\section{Type 2 veinlets}

Petrography: Type 2 veinlets are dominated by milky quartz and contain subordinate amounts of alkali feldspar, calcite, muscovite, biotite, calcic amphibole, and sphene (Fig. 16a and b). Ore minerals include scheelite, molybdenite, and pyrite. The veinlets range from a few millimeters to $15 \mathrm{~cm}$ in width.

The alkali feldspar forms subhedral cloudy grains (Fig. 16c). X-ray powder diffraction studies indicate 

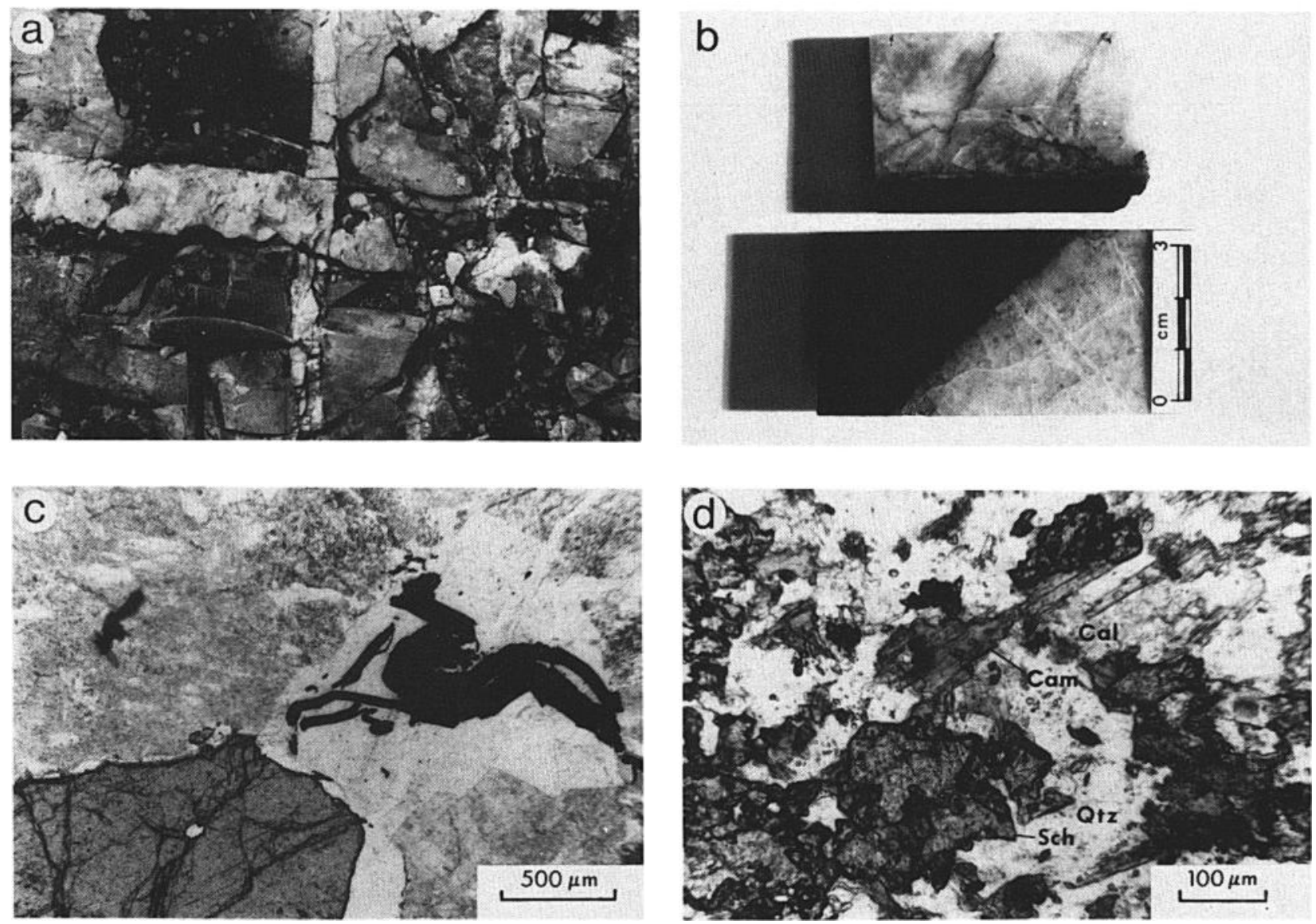

FIG. 16. Megascopic and microscopic aspects of type 2 veinlets. (a). Mutually perpendicular, steeply dipping type 2 veinlets in outcrop (see Fig. 2). Note the dominance of the north-south-oriented veinlet (horizontal in photograph). (b). Scheelite-bearing veinlets exhibiting a lack of associated pervasive wallrock alteration. Scheelite (light gray) occurs at the veinlet margins. (c). Photomicrograph of scheelite (high relief, lower left), molybdenite (black), alkali feldspar (medium gray, upper left and lower right), and quartz (light gray) at the margin of a veinlet (plane-polarized transmitted light). (d). Photomicrograph of type 2 mineralization hosted by a calc-silicate hornfels adjacent to a type 2 veinlet (see text). Assemblage includes calcic amphibole (Cam), calcite (Cal), quartz (Qtz), and sheelite (Sch) (plane-polarized transmitted light).

that it consists dominantly of orthoclase with lesser amounts of albitic plagioclase and microcline (D. J. Kontak, pers. commun., 1984). Petrographic relationships are consistent with the X-ray data: the feldspar grains are perthitic, with small patches of polysynthetically twinned albitic plagioclase exsolved from a dominantly orthoclase host and with small zones of twinned microcline. Modal analyses of these perthites indicate a mean composition of $\mathrm{Or}_{65} \mathrm{AB}_{35}$, consistent with a temperature in excess of $550^{\circ} \mathrm{C}$ prior to exsolution (Luth et al., 1974). Alkali feldspar is restricted to within $50 \mathrm{~m}$ of the monzogranite cupola.

Muscovite and biotite locally form subhedral booklets at the margins of veinlets. Muscovite also locally coexists with $\mathrm{K}$-feldspar and quartz in veinlets cutting the cupola, suggesting that these fluids were buffered with respect to their $a_{\mathbf{K}^{+}} / a_{\mathbf{H}^{+}}$ratio. Calcite occurs as a minor phase. Calcic amphibole and sphene commonly coexist as subhedral to euhedral grain aggregates at the margins of veinlets, particularly where these cut calc-silicate layers in the host metasediments.

Scheelite, the most abundant ore mineral, forms subhedral to euhedral grains, up to $1.5 \mathrm{~cm}$ across, and is localized at the margins of the veinlets (Fig. 16c). Molybdenite forms euhedral booklets, up to $1 \mathrm{~cm}$ in diameter, normally at the margins but locally throughout the veinlets. On the deposit scale, both ore minerals are markedly more abundant in the northern part of the study area, i.e., away from the monzogranite cupola. Pyrite, the only other sulfide identified in this veinlet type, occurs sparingly at the margins of veinlets.

Two other facies of mineralization, considered to be genetically related to type 2 veinlets, have been locally identified. The first consists of fine-grained 
molybdenite disseminated in a narrow leucocratic dike, and the second of disseminated, fine-grained scheelite in a calc-silicate unit adjacent to a type 2 quartz veinlet. The mineralized dike occurs within $250 \mathrm{~m}$ of the monzogranite cupola. It is fine to medium grained and consists of quartz $(30 \%)$, plagioclase $(25 \%)$, and potassium feldspar ( $10 \%)$, with secondary muscovite (25\%), calcite (10\%), and traces of molybdenite.

The fine-grained scheelite mineralization in the calc-silicate hornfels, ca. $800 \mathrm{~m}$ north of the cupola apex, has many of the characteristics of skarn mineralization yet cannot be classified as such due to the lack of evidence for pervasive metasomatism. The scheelite forms anhedral poikilitic grains hosted by a fine-grained, mineralogically unzoned calc-silicate rock (Fig. 16d) that is texturally and mineralogically identical to contact-metamorphosed marls elsewhere at the mine site. In addition to scheelite, the rock contains fine-grained quartz, calcite, calcic amphibole, plagioclase, clinozoisite, sphene, and ilmenite.

Alteration: The alteration associated with type 2 veinlets is neither as uniform nor as consistently developed as that associated with type 1 veinlets. In the monzogranite, the wall-rock alteration involved sericitization and carbonatization of igneous feldspars. Individual alteration envelopes extend up to $2 \mathrm{~cm}$ into the wall rock. Magmatic biotite in the vicinity of these veinlets is variably altered to chlorite. Pyrite occurs as a minor constituent of the alteration envelopes. In addition to occurring in the veinlets, molybdenite commonly forms fine-grained booklets, intimately intergrown with calcite mosaics, in the wall rock.

Alteration associated with type 2 veinlets hosted by metasediments is more erratically distributed than that in the monzogranite, and alteration envelopes generally extend less than $2 \mathrm{~mm}$ into the wall rocks. In pelitic metasediments, the only ubiquitous mineralogical change is the destruction of biotite. Other mineralogical changes encountered locally include the formation of sericite or plagioclase with minor amounts of chlorite and/or carbonate. In calc-silicate hornfels, the alteration associated with type 2 veinlets, though of limited extent, has generally depleted the wall rocks of calcium. The metamorphic assemblage, quartz + clinopyroxene + plagioclase + clinozoisite, is here converted to quartz + plagioclase + calcic amphibole, a less calcic assemblage.

It is inferred that the fluids responsible for type 2 mineralization did not appreciably interact with the wall rocks. Ca depletion from the calc-silicate hornfelses was negligible. The more intense alteration of the monzogranite, however, may have significantly affected the composition of the fluids.

Areal distribution: Type 2 veinlets are areally and volumetrically more significant than those of type 1 and are thus considered to have a greater economic potential. They are seen to cut the monzogranite cu- pola, the quartz-feldspar porphyry dike, and the metasediments, and have been observed at least 750 $\mathrm{m}$ north, $200 \mathrm{~m}$ south, $250 \mathrm{~m}$ east, and $400 \mathrm{~m}$ west of the apex of the cupola. In the vicinity of the intrusion, these veinlets have been intercepted by drilling at a depth of $500 \mathrm{~m}$. They are also exposed in the lower levels of the mine.

Fluid inclusions: All of the fluid inclusions in type 2 veinlets studied were hosted by quartz. The majority contain three phases (brine $+\mathrm{CO}_{2}$ liquid + vapor). Two-phase aqueous inclusions and inclusions comprising $\mathrm{CO}_{2}$ liquid + vapor are also encountered locally.

The three-phase inclusions and the two varieties of two-phase inclusions form two distinctive fluid inclusion assemblages, defined by the variability of the $\mathrm{H}_{2} \mathrm{O} / \mathrm{CO}_{2}$ ratios from one inclusion to another (Fig. 17). Near the cupola, $\mathrm{H}_{2} \mathrm{O} / \mathrm{CO}_{2}$ ratios in inclusions are fairly constant (Fig. 18a), implying the presence of an homogeneous one-phase fluid at the time of entrapment. An average composition of ca. 17 mole percent $\mathrm{CO}_{2}$ has been visually estimated for these inclusions. Locally, two-phase, presumably secondary, aqueous inclusions constitute a minor proportion of the population of fluid inclusions in these proximal veinlets. In contrast, away from the cupola to the north, both three-phase and the two varieties of twophase fluid inclusions are abundant. The $\mathrm{H}_{2} \mathrm{O} / \mathrm{CO}_{2}$ ratios are highly variable from one inclusion to another (Fig. 18b), suggestive of fluid immiscibility, i.e., $\mathrm{CO}_{2}$ effervescence during entrapment (Fig. 17).

Melting phenomena observed upon heating frozen three-phase inclusions provide a broad spectrum of compositional data. The lowest temperature transition observed was the melting of $\mathrm{CO}_{2}$ solid to $\mathrm{CO}_{2}$ liquid

S N

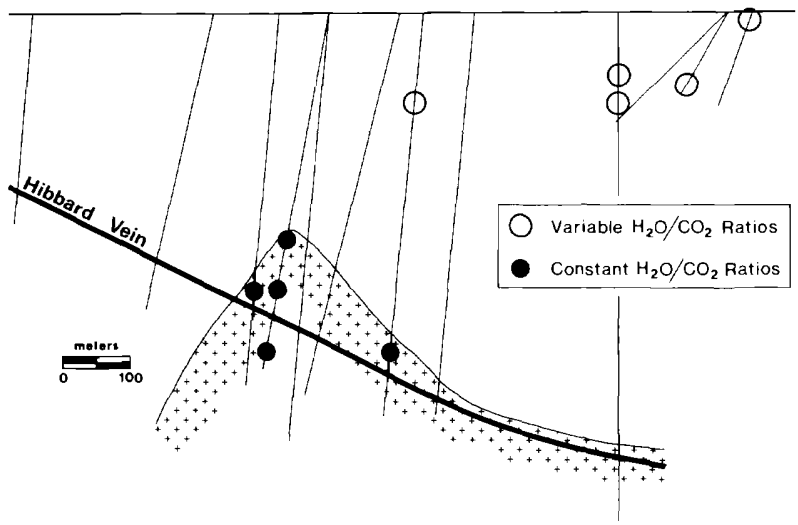

FIG. 17. Cross section depicting the areal distributions of fluid inclusion samples with variable and constant $\mathrm{H}_{2} \mathrm{O} / \mathrm{CO}_{2}$ ratios in type 2 veinlets, indicating an existence of effervescing and noneffervescing fluids, respectively, at the time of entrapment. Note the concentration of constant fluid ratios in the vicinity of the cupola. See Figure 2 for the location of the cross section. 

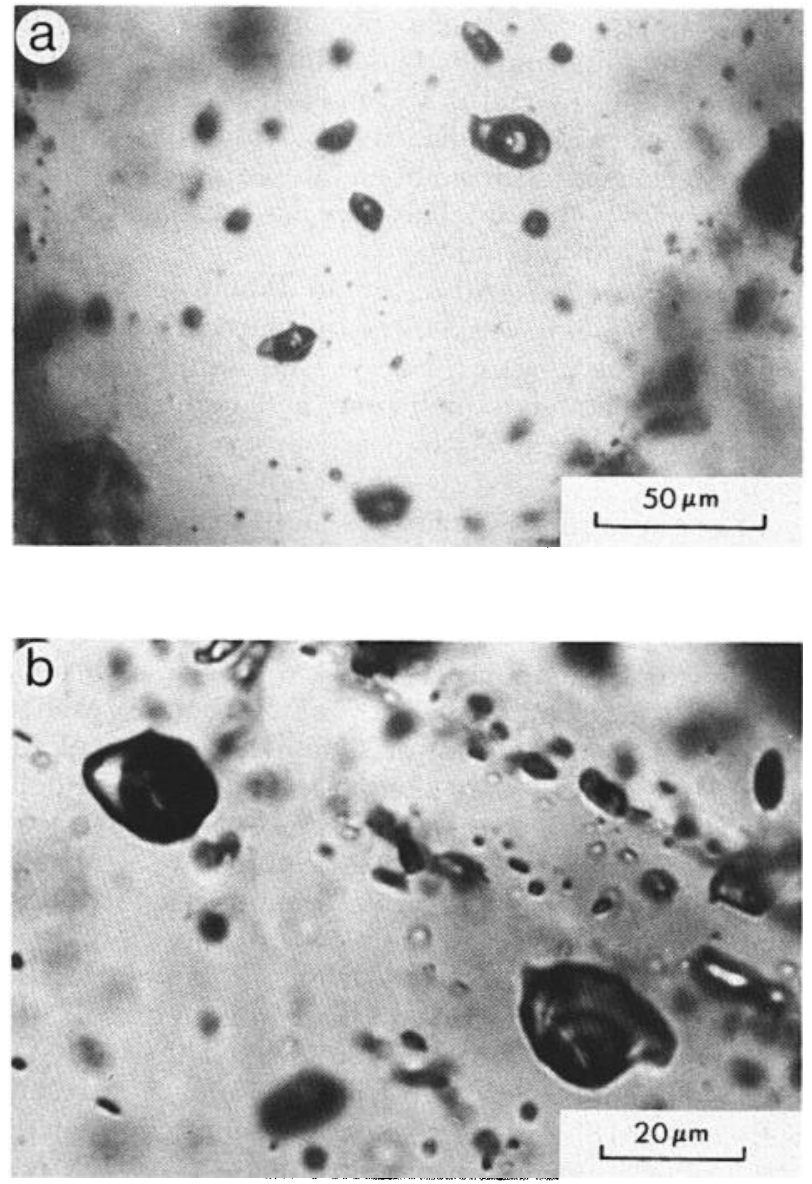

FiG. 18. Fluid inclusions from type 2 veinlets, hosted by quartz (plane-polarized transmitted light). (a). A group of primary threephase (brine $+\mathrm{CO}_{2}$ liquid + vapor) inclusions exhibiting constant phase ratios from inclusion to inclusion, indicating a homogenous, one-phase fluid at the time of entrapment. (b). A pair of primary three-phase (brine $+\mathrm{CO}_{2}$ liquid + vapor) inclusions exhibiting variability of phase ratios between inclusions, suggesting fluid immiscibility $\left(\mathrm{CO}_{2}\right.$ effervescence) at the time of entrapment.

in the presence of vapor, which, for pure $\mathrm{CO}_{2}$, occurs at $-56.6^{\circ} \mathrm{C}$. Observed melting temperatures for $\mathrm{CO}_{2}$ in fluid inclusions in type 2 veinlets, however, ranged from $-56.6^{\circ}$ to $-76^{\circ} \mathrm{C}$. In conjunction with homogenization temperatures for $\mathrm{CO}_{2}$ ranging from $-9.0^{\circ}$ to $+30.0^{\circ} \mathrm{C}$ this indicates the presence of methane in varying proportions, ranging from zero to in excess of $\mathbf{4 5}$ mole percent of the $\mathrm{CO}_{2}$-rich phase (Hollister and Burruss, 1976).

First-melting temperatures of brine from both twophase and three-phase inclusions, though commonly difficult to observe due to the small size of the inclusions, were found to range from $-8^{\circ}$ to $-50^{\circ} \mathrm{C}$, suggesting the presence of $\mathrm{CaCl}_{2}$ and $\mathrm{NaCl}$ as dissolved species (Crawford, 1981). The data for the threephase inclusions remain tentative, however, because the eutectic relations of $\mathrm{CO}_{2}$-bearing brines are not accurately known (Roedder, 1984).
Salinities of inclusions were estimated from the lastmelting temperatures of solids (ice or clathrate-hydrate). As expected, the last-melting temperatures show a marked bimodal distribution, the population above $0^{\circ} \mathrm{C}$ corresponding to the presence of clathratehydrates in three-phase inclusions and that below $0^{\circ} \mathrm{C}$ to the presence of ice in two-phase aqueous inclusions.

Last-melting temperatures of ice in two-phase aqueous inclusions ranged from $-13.0^{\circ}$ to $-1.8^{\circ} \mathrm{C}$, consistent with salinities of from 17 to 3 equiv wt percent $\mathrm{NaCl}$ (Potter et al., 1978). The last-melting temperatures of clathrate-hydrate in three-phase inclusions varied from $-4.3^{\circ}$ to $+9.8^{\circ} \mathrm{C}$, corresponding to salinities ranging from 19.6 to 1.0 equiv wt percent $\mathrm{NaCl}$, according to the data summarized by Collins (1979) and assuming no methane to be present. However, as previously demonstrated, methane locally constitutes in excess of 45 mole percent of the $\mathrm{CO}_{2}$ rich phase; thus, these estimates must be regarded with caution. Comparison of salinities of two-phase, aqueous fluid inclusions from type 2 veinlets, considered to be reliable, with those estimated for threephase fluid inclusions, however, indicates that these two populations are similar. Thus, it is concluded that the salinities estimated for methane-bearing, threephase fluid inclusions, on the basis of the experimental data for methane-free systems, are reasonable approximations. Similar arguments have been employed by Hollister and Burruss (1976) for methane-bearing inclusions.

A comparison of fluid inclusion salinity data for scheelite-bearing and for molybdenite-bearing type 2 veinlets reveals no significant differences (Fig. 19a and $b$ ). Thus, the salinity data indicate that both scheelite and molybdenite were deposited from a fluid with an average salinity of 6.7 equiv wt percent $\mathrm{NaCl}$. Furthermore, the similarity in the compositions of the fluids is consistent with the textural and mineralogical observations, recorded previously, which suggest that scheelite and molybdenite were transported and deposited by the same fluid under similar conditions.

Homogenization and decrepitation phenomena in fluid inclusions in type 2 veinlets, combined with fluid composition data, provide information on the temperatures and pressures at the time of mineralization. Fluid inclusion homogenization temperatures (to liquid) and decrepitation temperatures for inclusions near homogenization, in samples containing constant $\mathrm{H}_{2} \mathrm{O} / \mathrm{CO}_{2}$ ratios, ranged predominantly from $142^{\circ}$ to $405^{\circ} \mathrm{C}$ with a markedly higher frequency between $275^{\circ}$ and $325^{\circ} \mathrm{C}$ (Fig. 20a). The wide range suggests that many observations were from pseudo/secondary and secondary inclusions.

Homogenization data for fluid inclusions from assemblages with highly variable $\mathrm{H}_{2} \mathrm{O} / \mathrm{CO}_{2}$ ratios range from $144^{\circ}$ to $350^{\circ} \mathrm{C}$ with markedly higher frequencies between $175^{\circ}$ and $200^{\circ} \mathrm{C}$ and between $300^{\circ}$ and $325^{\circ} \mathrm{C}$ (Fig. 20b). Among the higher temperature 
a
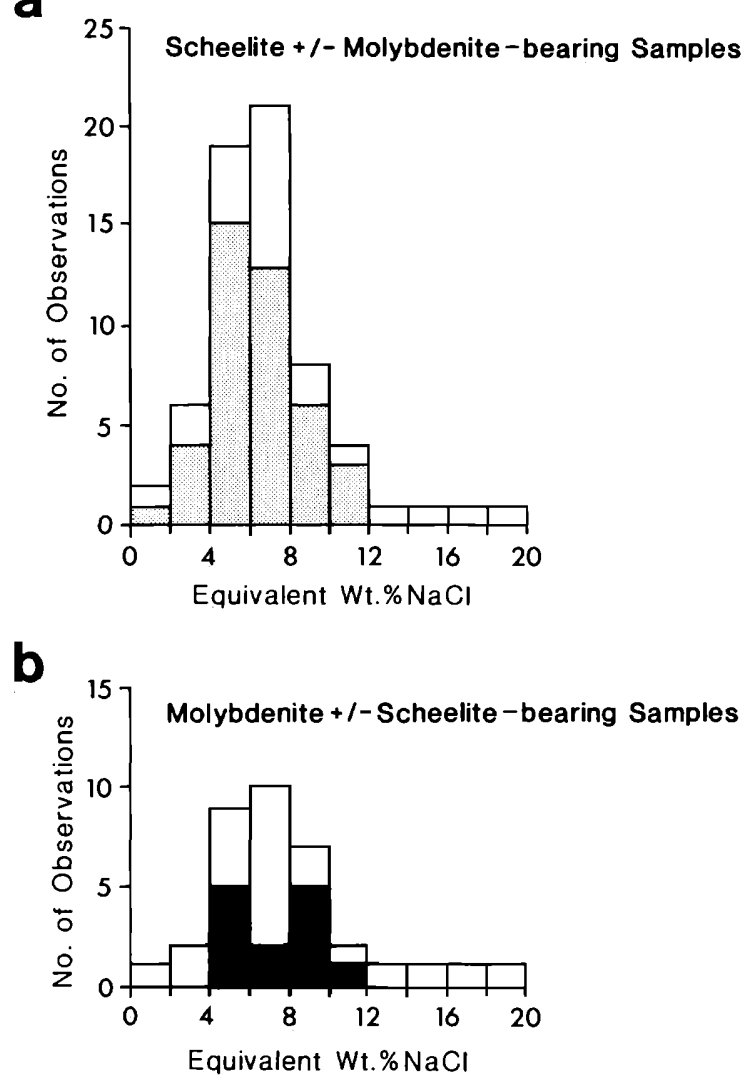

FIG. 19. Salinity data for fluid inclusions from type 2 veinlets, subdivided according to the associated ore minerals. Salinities estimated using the data of Potter et al. (1978) and Collins (1979). Note the similarity between the two plots. Unpatterned observations correspond to samples containing both scheelite and molybdenite. (a). Histogram for scheelite \pm molybdenite-bearing veinlets. Patterned observations correspond to samples lacking molybdenite. (b). Histogram for molybdenite \pm scheelite-bearing veinlets. Patterned observations correspond to samples lacking scheelite.

population, those three-phase inclusions dominated by brine generally homogenized to liquid, whereas those dominated by carbon dioxide typically decrepitated prior to homogenization. Further, both phenomena were observed in the sample and commonly occurred at similar temperatures, thus confirming the presence of two immiscible fluids at the time of entrapment. It should be noted that the lower temperature population of $\mathrm{H}_{2} \mathrm{O}$-rich inclusions is consistent with continuing effervescence depleting the fluid of $\mathrm{CO}_{2}$, but this may alternatively be interpreted as representing secondary inclusions. However, obvious secondary inclusions were avoided in the data collection process. Phase relations summarized by Bowers and Helgeson (1983) suggest that these inclusions should contain approximately 3 mole percent $\mathrm{CO}_{2}$, which probably occurs in the vapor phase because a second liquid phase was not observed at room temperature.
If the fluid inclusions from assemblages with highly variable $\mathrm{H}_{2} \mathrm{O} / \mathrm{CO}_{2}$ ratios were trapped from an effervescing fluid, i.e., under conditions corresponding to the solvus in the system $\mathrm{H}_{2} \mathrm{O}-\mathrm{CO}_{2}-\mathrm{NaCl}$, no temperature correction is necessary to adjust for entrapment at elevated pressures. Thus, it is inferred that ore deposition from an effervescing fluid occurred from approximately $350^{\circ}$ to $175^{\circ} \mathrm{C}$. The homogenization temperatures for fluid inclusions from samples exhibiting constant $\mathrm{H}_{2} \mathrm{O} / \mathrm{CO}_{2}$ ratios should be corrected for pressure, but these adjustments would be small because the fluids were trapped at conditions near their solvus. The overlap between the mode of these homogenization observations with those from samples exhibiting $\mathrm{CO}_{2}$ effervescence can be attributed either to slight compositional variations in the homogeneous fluid or to differences in trapping pressure between the two populations, because most of the samples with

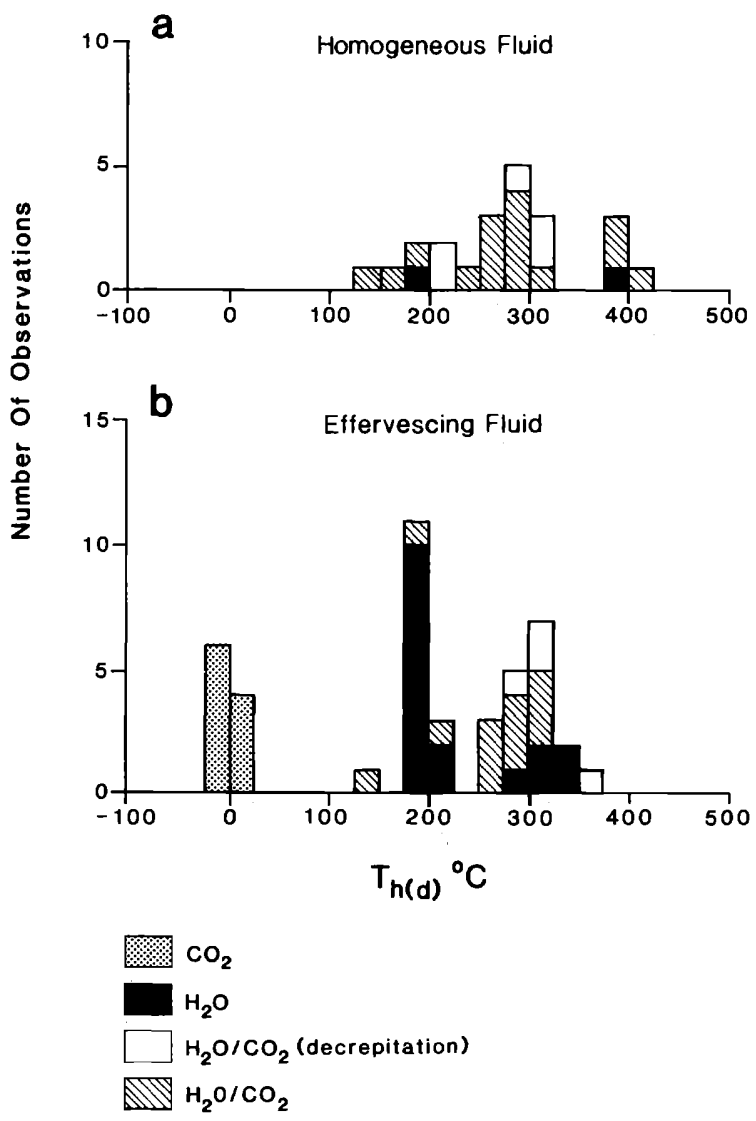

FIG. 20. Homogenization (and decrepitation) data for fluid inclusions from type 2 veinlets. Note the common occurrence of decrepitation in $\mathrm{CO}_{2}$-bearing inclusions. (a). Histogram of observations from samples with constant $\mathrm{H}_{2} \mathrm{O} / \mathrm{CO}_{2}$ ratios (suggesting the presence of a one-phase, homogeneous fluid at the time of entrapment). These observations require a pressure correction $\left(<50^{\circ} \mathrm{C}\right)$ to define entrapment temperatures. (b). Histogram of observations from samples with variable $\mathrm{H}_{2} \mathrm{O} / \mathrm{CO}_{2}$ ratios (suggesting the presence of fluid immiscibility, i.e., $\mathrm{CO}_{2}$ effervescence) at the time of entrapment. These observations (excluding $\mathrm{CO}_{2}$ inclusions) represent entrapment temperatures. 
evidence of a homogeneous fluid at the time of entrapment are from depths at least $300 \mathrm{~m}$ below those for samples with evidence of effervescence (Fig. 17).

Several lines of evidence suggest that types 1 and 2 mineralization occurred under a confining pressure of ca. $1.3 \mathrm{~kb}$. Metamorphic mineral equilibrium data, presented previously, constrain the pressure at the time of intrusion of the monzogranite cupola to a maximum of approximately $1.75 \mathrm{~kb}$. In addition, experimental studies conducted by Russian workers (Naumov et al., 1966; Naumov and Malinin, 1968) indicate that decrepitation of fluid inclusions in quartz begins at internal pressures of 860 bars or greater. Decrepitation of three-phase inclusions during heating was not uncommon in this study (Fig. 20). Thus, these fluid inclusions were probably trapped at pressures of over 860 bars. As previously stated, if the fluid inclusions in the veinlets with variable $\mathrm{H}_{2} \mathrm{O} / \mathrm{CO}_{2}$ ratios were trapped from an effervescing fluid, the homogenization temperatures are the entrapment temperatures. Thus, if the configuration of the reaction corresponding to $\mathrm{CO}_{2}$ effervescence is known for the composition of the homogeneous fluid that undergoes effervescence, then the temperature of entrapment defines the pressure. It has been demonstrated that the noneffervescing homogeneous fluid consisted of approximately 6.7 equiv wt percent $\mathrm{NaCl}$ and approximately 17 mole percent $\mathrm{CO}_{2}$. The immiscibility curve shown in Figure 21 was derived from the data of Bowers and Helgeson (1983) for a system consisting of 6 wt percent $\mathrm{NaCl}$ and $\mathrm{X}_{\mathrm{CO}_{2}}=0.17$. Thus, effervescence at $350^{\circ} \mathrm{C}$, the maximum temperature for samples with evidence of effervescence, defines a confining pressure of approximately $1.3 \mathrm{~kb}$ (Fig. 21), which is consistent with the constraints provided by metamorphic equilibria and fluid inclu-

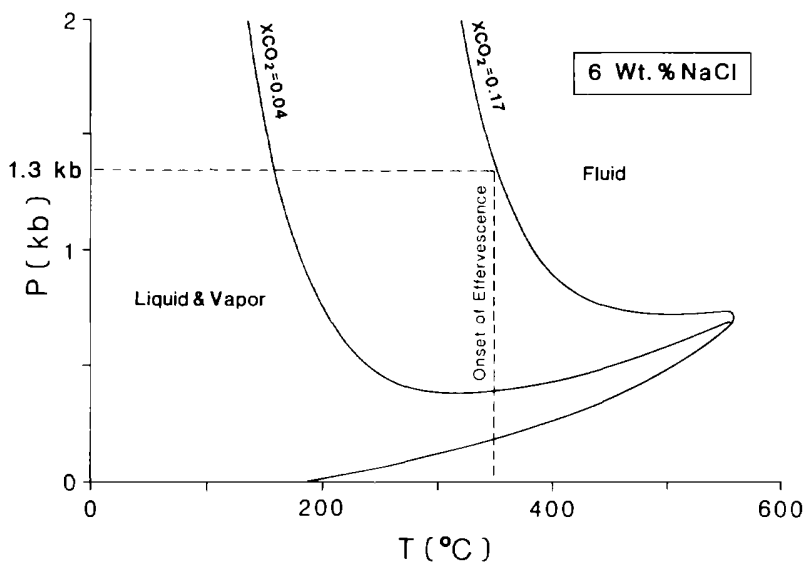

FIG. 21. Phase relations in the system $\mathrm{H}_{2} \mathrm{O}-\mathrm{CO}_{2}-\mathrm{NaCl}$, from Bowers and Helgeson (1983). Pressure-temperature diagram of $\mathrm{CO}_{2}$ solubility in a 6 percent $\mathrm{NaCl}$ brine. The vertical dashed line indicates the onset of $\mathrm{CO}_{2}$ effervescence at Lake George and therefore defines the corresponding confining pressure (see text). sion decrepitation data. It should be noted that the presence of methane increases the thermal stability of the $\mathrm{H}_{2} \mathrm{O}-\mathrm{CO}_{2}$ solvus (Holloway, 1984), but this was not considered in the above analysis due to a lack of experimental data.

\section{Type 3 veinlets}

Type 3 veinlets, comprising prehnite, molybdenite, and quartz, with minor calcic amphibole, calcite, and chlorite, are much less abundant than types 1 and 2 . Type 3 veinlets locally observed to cut and offset type 2 . They are restricted to within $350 \mathrm{~m}$ of the cupola and have only been observed to be hosted by metasediments. Their widths do not exceed $2 \mathrm{~mm}$. Prehnite constitutes up to 95 percent of the veinlet mineralogy. Molybdenite, the only sulfide observed, is typically intergrown with prehnite and localized at the veinlet margins. Quartz can constitute up to 90 percent of some veinlets. Type 3 veinlets lack microscopically visible alteration envelopes in calc-silicate wall rocks, but they have weakly to moderately developed envelopes in the pelites.

\section{Discussion}

\section{Physiochemical controls on scheelite and molybdenite deposition}

The available experimental data on tungsten speciation and scheelite solubility in hydrothermal fluids under geologically reasonable conditions are limited (Bryzgalin, 1976; Foster, 1977; Wesolowski et al., 1982, 1984; Manning and Henderson, 1984). Even fewer data are available on molybdenum speciation and molybdenite solubility (Smith et al., 1980; Candela and Holland, 1984).

Bryzgalin (1976) experimentally determined the solubility of tungstic acid $\left(\mathrm{H}_{2} \mathrm{OWO}_{4}\right)$ from $300^{\circ}$ to $400^{\circ} \mathrm{C}$ in 0.5 to $2.0 \mathrm{M} \mathrm{NaCl}$ and $\mathrm{KCl}$ aqueous solutions and found that solubility was proportional to both salinity and temperature. Foster (1977) determined the solubility of scheelite in 0.0 to $1.0 \mathrm{M} \mathrm{KCl}$ aqueous solutions at pressures of 1 and $2 \mathrm{~kb}$ and at temperatures ranging from approximately $250^{\circ}$ to $560^{\circ} \mathrm{C}$. In $0.5 \mathrm{M} \mathrm{KCl}$ solutions buffered by the assemblage quartz + potassium feldspar + muscovite at $1 \mathrm{~kb}$ (i.e., under conditions analogous to those defined for type 2 veinlets), he determined that scheelite solubility increases from $59 \mathrm{ppm}$ at $354^{\circ} \mathrm{C}$ to $277 \mathrm{ppm}$ at $561^{\circ} \mathrm{C}$. In 1.0 $M \mathrm{KCl}$ solutions, the increase in solubility with temperature was more pronounced. He also concluded that $\mathrm{H}_{2} \mathrm{WO}_{4}$ is the dominant tungsten species in these fluids. Wesolowski et al. (1982, 1984), conclude from experimental data that $\mathrm{HWO}_{4}^{-}$and $\mathrm{WO}_{4}^{-2}$ are the dominant tungsten species at elevated temperatures in moderately saline solutions of slightly acidic to basic $\mathrm{pH}$. Although Higgins (1980), on the basis of fluid inclusion data for tungsten vein deposits, suggested 
that tungsten may form carbonate and bicarbonate complexes in $\mathrm{CO}_{2}$-rich fluids, Manning and Henderson (1984) do not consider these as viable means of tungsten transport. However, they conclude from their experimental work at $800^{\circ} \mathrm{C}$ and $1 \mathrm{~kb}$ that complexing with chlorine may be important in tungsten transport in hydrothermal fluids and suggest that $\left(\mathrm{WO}_{3}\right)_{2} \mathrm{Cl}^{-}$may be the dominant species at low chloride concentrations.

Smith et al. (1980) theoretically evaluated the solubility of molybdenite in slightly acidic aqueous solutions at $250^{\circ}, 300^{\circ}$, and $350^{\circ} \mathrm{C}$ and concluded that solubilities ranged up to several thousand ppm at $350^{\circ} \mathrm{C}$, decreasing exponentially with temperature, conditions which are analogous to those inferred for both type 1 and 2 veinlets at Lake George. Further, they suggest that molybdenum is dominantly transported as $\mathrm{HMoO}_{4}^{-}$with lesser $\mathrm{H}_{2} \mathrm{MoO}_{4}$ and $\mathrm{MoO}_{3} \mathrm{~F}^{-}$, and that chloride and sulfide complexes are not significant. Candela and Holland (1984) also conclude that molybdenum is probably transported as molybdate species and that fluoride and chloride complexes are unimportant.

Foster (1977) and Foster et al. (1978) suggest that the factors influencing tungsten deposition from a given hydrothermal fluid are temperature, $\mathrm{pH}$, $a_{\mathrm{Ca}^{+2}}, a_{\mathrm{Fe}^{+2}}, f_{\mathrm{O}_{2}}$, and $f_{\mathrm{S}_{2}}$, of which $a_{\mathrm{Fe}^{+2}}, f_{\mathrm{O}_{2}}$, and $f_{\mathrm{S}_{2}}$ are strongly related due to their effect on the stability of the iron sulfides and oxides, and hence, on the ferrous iron concentration in the hydrothermal solution and on wolframite stability. In the case of both type 1 and 2 veinlets at Lake George, variations in the latter three parameters are considered of subordinate importance; no wolframite has been observed in the study area. The minor importance of $f_{\mathrm{O}_{2}}$ and $f_{\mathrm{S}_{2}}$ is also confirmed by the broad overlap of the stability field of coexisting scheelite and molybdenite with that of pyrite and pyrrhotite (Hsu, 1977).

Increasing $a_{\mathrm{Ca}^{+2}}$ in the hydrothermal solution is also considered unimportant in effecting scheelite deposition in type 1 veinlets because calcium metasomatism of the wall rocks, regardless of their chemical composition, is a ubiquitous feature. Calcium and tungsten were clearly transported in the same hydrothermal fluid. Hence, metasomatism of the wall rocks would have depleted the fluid of calcium, a process that is not inherently conducive to scheelite deposition. We therefore conclude that changes in the remaining factors, temperature and/or $\mathrm{pH}$, must have exerted an effect on the system to offset the contrary effect of calcium metasomatism of the wall rocks.

The thermal controls on type 1 mineralization can, in part, be assessed qualitatively from fluid inclusion data and the areal distributions of veinlet-filling, alteration, and metamorphic assemblages. These data suggest that the monzogranite cupola was the thermal focus for this and subsequent stages of W-Mo min- eralization, and our fluid inclusion data demonstrate that type 1 hydrothermal activity occurred from $559^{\circ}$ to $280^{\circ} \mathrm{C}$. Foster's (1977) experimental data suggest that scheelite solubility would decrease fivefold over this range, and we therefore infer that temperature gradients relative to the stock contributed to scheelite precipitation in type 1 veinlets.

The effect of $\mathrm{pH}$ on scheelite deposition in these veinlets may be qualitatively assessed from veinletfilling and alteration assemblages, in conjunction with experimental data from the literature. The absolute $\mathrm{pH}$ of the fluids responsible for type 1 mineralization is uncertain, but from the late precipitation of calcite relative to other veinlet-filling phases in type 1 veinlets, they were probably initially slightly acidic, becoming more basic with continued hydrogen metasomatism of the wall rocks. Wesolowski et al. (1982, 1984) have demonstrated that, in their experimental fluids, increasing $\mathrm{pH}$ dramatically increased the abundance of $\mathrm{WO}_{4}^{-2}$ at the expense of $\mathrm{HWO}_{4}^{-}$at $290^{\circ} \mathrm{C}$, particularly in the $\mathrm{pH}$ range of 4.5 to 5.5 , conditions broadly analogous to those inferred for the mineralizing fluids. Such an increase in the concentration of $\mathrm{WO}_{4}^{-2}$ would prompt scheelite deposition. Thus, it can be concluded that increasing $\mathrm{pH}$ through wall-rock interaction may also have been involved in type 1 scheelite deposition.

In part, the compositions of the calc-silicate minerals in type 1 veinlets also may have been controlled by temperature and/or $\mathrm{pH}$. The progressive zoning of coexisting garnets and clinopyroxenes, from grossular-rich cores to almandine-rich rims, and from hedenbergitic cores to more diopsidic rims, respectively (Figs. 11 and 12), may be correlated with the late deposition of scheelite through a reaction such as (cf. Newberry, 1983):

$$
\begin{gathered}
3 \mathrm{CaFeSi}_{2} \mathrm{O}_{6}+\mathrm{Ca}_{3} \mathrm{Al}_{2} \mathrm{Si}_{3} \mathrm{O}_{22}+6 \mathrm{H}_{2} \mathrm{WO}_{4} \\
\text { in clinopyroxene in garnet aqueous } \\
=6 \mathrm{SiO}_{2}+\mathrm{Fe}_{3} \mathrm{Al}_{2} \mathrm{Si}_{3} \mathrm{O}_{12}+6 \mathrm{CaWO}_{4}+6 \mathrm{H}_{2} \mathrm{O} . \\
\text { quartz in garnet scheelite }
\end{gathered}
$$

Thus the factors, temperature and $\mathrm{pH}$, controlling the speciation of tungsten in these fluids, and therefore, the solubility of scheelite, would also have determined the compositions of the hydrothermal garnets and clinopyroxenes. It can be concluded that there is a sympathetic relationship between the abundances of subcalcic (i.e., almandine-enriched) garnet and scheelite in type 1 veinlets at Lake George; this is contrary to the conclusions of Newberry (1983), who advocates an antipathetic paragenetic relationship between subcalcic garnet and scheelite in skarn environments. His further proposal, that there is, overall, a positive correlation between subcalcic garnet and tungsten grade in skarn deposits, may, however, be applicable to the calc-silicate-bearing veinlets at Lake George. 
With regard to type 2 veinlets, increases in $a_{\mathrm{Ca}^{+2}}$ are again considered to have been unimportant in producing scheelite deposition; the general lack of wall-rock alteration in metasediments suggests that these later fluids were essentially insulated from cationic exchange with the wall rocks.

Mineral equilibria and fluid inclusion data indicate that the type 2 mineralizing fluids were initially in excess of $550^{\circ} \mathrm{C}$ within the cupola but cooled with increasing distance from the intrusion to as low as $175^{\circ} \mathrm{C}$. As with type 1 veinlets, this temperature range coincided with marked decreases in scheelite solubility in experimental systems and we conclude that decreasing temperature may again have had a positive influence on scheelite precipitation.

The assemblage quartz + potassium feldspar + muscovite in type 2 veinlets hosted by the monzogranite indicates that the hydrothermal solution was buffered with respect to its $a_{\mathrm{K}^{+}} / a_{\mathrm{H}^{+}}$ratio. By combining fluid inclusion salinity and homogenization data with the $\mathrm{Na} / \mathrm{K}$ geothermometer equation (Truesdell, 1984), a potassium concentration may be estimated. This, together with the experimental curves of Montoya and Hemley (1975) for K-feldspar-muscovite equilibria, indicates a $\mathrm{pH}$ of 4.8 to 5.0 for the fluid prior to effervescence at $350^{\circ} \mathrm{C}(\mathrm{Seal}, 1984)$. Henley (1984a) demonstrates that effervescence of $\mathrm{CO}_{2}$ from an aqueous fluid results in an increase in $\mathrm{pH}$ through the reaction:

$$
\mathrm{H}_{2} \mathrm{CO}_{3_{(a q)}}=\mathrm{H}_{2} \mathrm{O}+\mathrm{CO}_{2},
$$

with dissolved carbonate dominantly occurring as $\mathrm{HCO}_{3}^{-}$; it is thus related to carbonic acid through the reaction:

$$
\mathrm{H}_{2} \mathrm{CO}_{3}=\mathrm{HCO}_{3}^{-}+\mathrm{H}^{+} \text {. }
$$

The change in $\mathrm{pH}$ in the type 2 fluids can be quantified using these relationships, assuming that it resulted entirely from effervescence and that the fluids represented a closed system with respect to chemical interaction with the wall rocks after entering the metasediments. Utilizing thermochemical data reported by Henley (1984b) and Bowers et al. (1984), an increase in $\mathrm{pH}$ of 0.3 to 0.4 is calculated for the transition from an initial aqueous fluid containing 17 mole percent dissolved $\mathrm{CO}_{2}$ at $350^{\circ} \mathrm{C}$ to one with ca. 4 mole percent at $175^{\circ} \mathrm{C}($ Seal, 1984).

As stated previously, Wesolowski et al. (1982, 1984) have demonstrated that in this $\mathrm{pH}$ range slight increases in $\mathrm{pH}$ significantly increase the concentration of $\mathrm{WO}_{4}^{-2}$ in solution and thus would promote scheelite deposition. They also demonstrate that, from $290^{\circ}$ to $150^{\circ} \mathrm{C}$, the concentration of $\mathrm{WO}_{4}^{-2}$ increases with decreasing temperature, consistent with the scheelite solubility data of Foster (1977); in fact, this may have been a dominant control. As with type 1 veinlets, increasing $\mathrm{pH}$ is inferred to have had a pos- itive influence on scheelite deposition. For type 2 veinlets, the general trend of increased scheelite deposition as a function of both decreasing temperature, dependent upon distance from the cupola, and increasing $\mathrm{pH}$, dependent upon $\mathrm{CO}_{2}$ effervescence, is qualitatively illustrated in Figure 22 (cf. Fig. 17).

Molybdenite deposition in both veinlet types also appears to have been controlled by decreasing temperature, in conformity with the data of Smith et al. (1980).

\section{Comparison with other W(-Mo) deposits}

In seeking analogues for the Lake George scheelitemolybdenite mineralization, we do not herein address its possible genetic relationships with the superimposed $\mathrm{Sb}$ veins (see Seal et al., in press). Whereas the metal association $\mathrm{W}-\mathrm{Sb}$ is comparatively widespread (e.g., Ahlfeld and Schneider-Scherbina, 1964; Maucher, 1965), those of W-Mo-Sb or Mo-Sb are not.

A spectrum of mineral deposits exists in which scheelite is associated with broadly equivalent or lesser amounts of molybdenite. These are:

1. "Oxidized" (Einaudi et al., 1981) W > Mo skarn deposits (e.g., King Island (Edwards et al., 1956) and Sangdong (John, 1963; Moon, 1984; but cf. Einaudi et al., 1981, and Newberry, 1983). Molybdenitequartz vein and veinlet systems are developed to a variable extent in such deposits and have recently been shown to be an important, if secondary, component of the mineralized system at Sangdong (Moon, 1984). In the northern Canadian cordillera, Dick (1979) distinguishes a series of oxidized W(-Mo) skarns which are, in general, much smaller than the

S

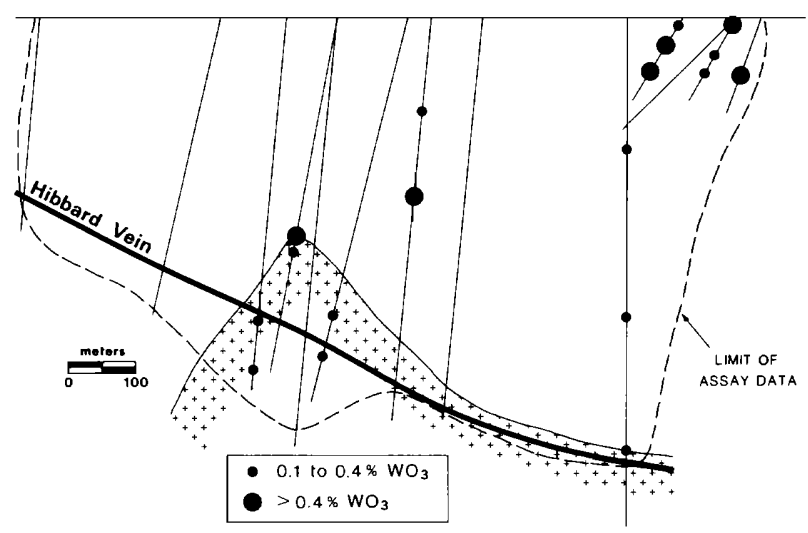

Fig. 22. Cross section depicting the distribution of tungsten grades (averaged over 3-m intervals). Compare with Figure 7 depicting zone of $\mathrm{CO}_{2}$ effervescence. Dashed line represents the limits of assay data. From unpublished data (Durham Resources, Inc., 1982). 
reduced $\mathrm{W}(-\mathrm{Cu})$ deposits. In all of the these deposits the great bulk of the scheelite is contained in garnetrich exoskarn bodies within horizons of pure or impure marble, but quartz veinlet and endoskarn mineralization is also represented.

2. Complex, skarn plus stockwork, W-Mo deposits. This class of deposit is exemplified by the very large Tyrnyauz center (Polkanov, 1978; Tvalchrelidze, 1982) in the Soviet Caucasus. The class comprises oxidized, scheelite-rich, W(-Mo) exoskarns in marble and in calc-silicate zones in metapelitic hornfels, and molybdenite-quartz vein skarns in granitoid intrusions and hornfelses. In Canada, smaller deposits of this class have been documented in northern British Columbia: namely, the Mount Reed sector of the Mount Reed-Mount Haskin district (Gower et al., 1985) and the Boya prospect (Moreton et al., 1983). In these generally low-grade systems, both scheelite and molybdenite occur in skarn lenses and as stockworks.

3. Scheelite (-molybdenite) stockworks. The recent work of Noble et al. (1984) has clarified the nature of the Logtung W-Mo deposit, southern Yukon, and has demonstrated that scheelite-rich stockwork, or porphyry, deposits may constitute significant concentrations of tungsten. This is also apparent from Yan et al.'s (1980) description of the Yanchuling W-Mo deposit, southern China. The Glacier Gulch (or Hudson Bay Mountain) deposit in British Columbia (Bright and Jonson, 1976) and that at Auxelles-Haut, Belfort, France (Coutellier, 1974) are probably broadly comparable. In such deposits, the vast bulk of scheelite is contained in veinlets rather than skarns. Sheeted vein systems may represent a significant component of these deposits and, as at Auxelles-Haut (A. H. Clark, unpub. data), may be rich in scheelite. Other, probably smaller, scheelite deposits comprise an association of quartz veins and sheeted vein swarms (e.g., Otani, Japan: Imai et al., 1978; A. H. Clark, unpub. data).

From the above, it is evident that the Lake George scheelite-molybdenite veinlet systems show the closest analogies with the tungsten stockwork clan. Features shared by Lake George and Logtung (Noble et al., 1984) include: (1) the association with epizonal stocks of biotite (-hornblende) monzogranite, with $\mathrm{A} / \mathrm{CNK} \simeq 1$, and with porphyritic felsic dikes; (2) the mixed calcareous-noncalcareous nature of the metapelitic country rocks which host the bulk of the stockwork mineralization; (3) the premineralization development of calc-silicate hornfels, in part through bimetasomatic reactions during metamorphism; (4) the absence of pervasive hydrothermal alteration; (5) the occurrence of several stages of $\mathrm{W}$ - and/or Mobearing veinlets; (6) the emplacement of porphyry dikes between the first and second stage of mineral- ization; (7) the association of calc-silicate minerals with the earliest mineralization; (8) the lack of a systematic W vs. Mo zonation relative to the center; and (9) the association with late-stage, base metal sulfide veins, containing, among others, sphalerite, galena, arsenopyrite, and bismuthinite. This stage is apparently better developed at Logtung, unless the major $\mathrm{Sb}$ veins at Lake George are representative of such mineralization.

It is of interest that the W(-Mo) stockwork mineralization of the Mistberget prospect, at the northeast margin of the Oslo ensialic rift, Norway, is similar in many respects to both Lake George and Logtung. In this area, extensive development of scheelite (-molybdenite) veinlets, rich in garnet (grossular-andradite) occurred in partly calcareous metapelitic hornfelses, adjacent to large dikelike bodies of alkali biotite granite, following an episode of calc-silicate hornfels development (Ihlen, 1978; Ihlen and Vokes, 1978; P. M. Ihlen, pers. commun., 1980). Later veinlets contain scapolite, and finally, base metal sulfides.

Despite these similarities, the Lake George stockwork differs from that at Logtung (as well as, probably, Mistberget) in several secondary respects. The Lake George monzogranite is both markedly less silicic ( 67 vs. $+75 \mathrm{wt} \% \mathrm{SiO}_{2}$ ), and from the occurrence of secondary magnetite at Logtung, considerably more reduced than monzogranite associated with that deposit. The latter feature is probably reflected in the persistent deposition at Lake George of Mo-poor scheelite and molybdenite rather than molybdoscheelite (Hsu, 1977; cf. Noble et al., 1984) and in the (apparently) lower andradite contents of the garnets in the early formed veins. As noted above, the subequal concentration of $\mathrm{CH}_{4}$ and $\mathrm{CO}_{2}$ in some type 2 veinlet fluids suggests that relatively reducing conditions prevailed during mineralization at Lake George. The above relationships indicate (cf. Ishihara, 1977) that scheeliterich stockwork deposits may be generated by both magnetite- and ilmenite-series granitoids (Ishihara, 1981) and in both moderately and strongly fractionated magmatic systems. In the latter context, it is of interest that Lake George lacks the enrichments in $\mathbf{F}$ and Sn shown by the Logtung deposit (Noble et al., 1984).

Although the earlier vein systems at both Logtung and Mistberget are rich in garnet and other calc-silicate minerals, and presumably represent local enrichments in Ca relative to the metapelitic host rocks, these deposits appear to lack the locally intense $\mathrm{Ca}$ metasomatism evident around many of the type 1 veinlets at Lake George. Restricted $\mathrm{Ca}(<\mathrm{Na})$ metasomatism is associated with the early stages of some calc-alkaline porphyry $\mathrm{Cu}(-\mathrm{Mo})$ deposits (e.g., Yerington: Carten, 1979), but more intense calc-silicate development, similar to that at Lake George, is displayed by some alkalic porphyry $\mathrm{Cu}$ deposits (e.g., 
Galore Creek: Allen et al., 1976). We propose that the inferred high concentrations of $\mathrm{CaCl}_{2}$ in solution may reflect equilibrium between early, juvenile fluids and a relatively Ca-rich monzogranite magma (see Burnham and Ohmoto, 1980).

The apparently large Yanchuling deposit (Yan et al., 1980) differs from both Lake George and Logtung in the occurrence of extensive disseminated scheelite, the involvement of breccia bodies, and the development of apparently pervasive potassic and phyllic alteration. Calcic alteration has not been reported.

The widespread intimate association of scheelite and molybdenite at Lake George, contrasting with the more complex ore mineral relationships at Logtung, potentially renders more clearcut the factors influencing the distributions of $\mathrm{W}$ and $\mathrm{Mo}$ in the former deposit, which, in addition, is apparently simpler in structure. Our fluid inclusion data provide a geochemical framework for clarification of the controls on W-Mo ore grades, and in particular, highlight the role of temperature decrease, and probably to a lesser extent, $\mathrm{CO}_{2}$ effervescence in the development of the richer northern concentration of type 2 veinlets at Lake George. Such data are at present lacking for the Logtung deposit.

\section{Summary of Conclusions}

The Lake George scheelite-molybdenite mineralization is considered to be a lower Paleozoic (Upper Silurian) example of a W(-Mo) stockwork and is comparable in many respects to the large Logtung deposit (Noble et al., 1984). We prefer to employ the term "stockwork" rather than "porphyry" to describe this type of deposit because of the coarse-grained, only weakly porphyritic nature of the early monzogranite stocks and the absence of significant pervasive hydrothermal alteration.

The following salient features of the Lake George mineralization should be emphasized:

1. Both the tungsten-molybdenum and antimony mineralizations at Lake George occurred after penetrative deformation of the Silurian turbiditic sediments and after emplacement of the monzogranite cupola. Neither mineralization has been modified by subsequent folding.

2. Hydrothermal activity followed the contact metamorphism associated with the monzogranite cupola, as indicated by the mineralogically buffered nature of the metamorphic fluids associated with the calc-silicate hornfelses.

3. Tungsten-molybdenum mineralization has been identified in three distinctive veinlet types, 1,2 , and 3 , of which only types 1 and 2 appear to be of economic significance.

4. Type 1 mineralization comprises calc-silicate quartz veinlets with ubiquitously associated calcium and hydrogen metasomatic alteration envelopes. Type 1 hydrothermal activity involved an aqueous brine $($ avg $=10.0$ equiv wt $\% \mathrm{NaCl})$ at temperatures ranging from ca. $560^{\circ}$ to $288^{\circ} \mathrm{C}$.

5 . Type 2 veinlets are dominated by quartz with lesser amounts of scheelite and molybdenite; they lack strongly developed alteration envelopes. Hydrothermal activity occurred from a $\mathrm{CO}_{2}$-bearing solution (avg $=6.7$ equiv wt $\% \mathrm{NaCl}$ ) over a temperature range from in excess of $550^{\circ}$ down to $175^{\circ} \mathrm{C}$.

6. Decreasing temperature and increasing $\mathrm{pH}$ were the dominant controls on scheelite deposition in both major veinlet types, whereas temperature alone was probably responsible for molybdenite deposition. In each system temperature was dependent upon distance from the cupola. Factors controlling $\mathrm{pH}$, however, were specific to each veinlet type. Thus, interaction of the hydrothermal fluids with the wall rocks, through hydrogen metosomatism, controlled $\mathrm{pH}$ in type 1 fluids, whereas $\mathrm{CO}_{2}$ effervescence controlled $\mathrm{pH}$ in type 2 fluids.

\section{Acknowledgments}

We greatly appreciate the financial support given by Durham Resources, Inc., during the course of this research, and the company's permission to publish this paper. Bert Bourgoin, Mine Manager, is particularly thanked for his unstinting encouragement and good advice. W. D. Sinclair reviewed an earlier version of the manuscript and his comments are greatly appreciated. At Queen's University, discussions with Dugald Carmichael and Peter Roeder were greatly appreciated. Bob Foster, David Kempson, Frank Dunphy, Bob Carroll, and Roger Innes provided technical assistance. Chris Peck prepared the illustrations, and Larke Zarichny and Ann MacDonald typed the revised manuscript.

This research was funded in part by a Natural Sciences and Engineering Research Council of Canada operating grant to A. H. Clark.

Finally, we thank R. B. Scratch for suggesting this research topic.

August 16, 1985; September 15, 1986

\section{REFERENCES}

Ahlfeld, F., and Schneider-Scherbina, A., 1964, Los yacimientos minerales y de hidrocarburos de Bolivia: Bolivia Dept. Nac. Geología, Bol. 5, 388 p.

Allen, D. G., Penteleyev, A., and Armstrong, A. T., 1976, Galore Creek: Canadian Inst. Mining Metallurgy Spec. Vol. 15, p. 402414.

Bowers, T. S., and Helgeson, H. C., 1983, Calculation of the thermodynamic and geochemical consequences of nonideal mixing in the system $\mathrm{H}_{2} \mathrm{O}-\mathrm{CO}_{2}-\mathrm{NaCl}$ fluids at high temperatures and pressures: Geochim. et Cosmochim. Acta, v. 47, p. 1247-1275.

Bowers, T. S., Jackson, K. J., and Helgeson, H. C., 1984, Equilibrium activity diagrams for coexisting minerals and aqueous solutions at pressures and temperatures to $5 \mathrm{~kb}$ and $600^{\circ} \mathrm{C}$ : New York, Springer-Verlag, 397 p. 
Bright, M. J., and Jonson, D. C., 1976, Glacier Gulch (YorkeHardy): Canadian Inst. Mining Metallurgy Spec. Vol. 15, p. 455-461.

Bryzgalin, O. V., 1976, On the stability of tungstic acid in aqueous salt solutions at high temperatures: Geochemistry Internat., v. 13, p. 147-154.

Burnham, C. W., 1979, Magmas and hydrothermal fluids, in Barnes, H. L., ed., Geochemistry of hydrothermal ore deposits: New York, Wiley Intersci., p. 71-136.

Burnham, C. W., and Ohmoto, H., 1980, Late-stage processes of felsic magmatism: Soc. Mining Geologists Japan Spec. Issue 8, p. 1-11

Candela, P. A., and Holland, H. D., 1984, The partitioning of copper and molybdenum between silicate melts and aqueous fluids: Geochim. et Cosmochim. Acta, v. 48, p. 373-380.

Carten, R. B., 1979, Na-(Ca) metasomatism and its time-space relationship to $\mathbf{K}$ metasomatism at the Yerington, Nevada, porphyry deposit [abs.]: Geol. Soc. America Abstracts with Programs, v. 11, p. 399.

Collins, P. L. F., 1979, Gas hydrates in $\mathrm{CO}_{2}$-bearing fluid inclusions and the use of freezing data for estimation of salinity: ECON. GEOL., v. 74, p. 1435-1444.

Coutellier, G., 1974, Les minéralisations en tungstène de l'intrusion d'Auxelles-Haut (Territoire de Belfort): Etude géologique et metallogenique: Univ. Nancy, Mem., Diploma Etudes Sup., Sci. Nat., 115 p.

Crawford, M. L., 1981, Phase equilibria in aqueous fluid inclusions: Toronto, Mineralog. Assoc. Canada, Short Course Handbook, v. 6, p. 75-100.

Dick, L. A., 1979, Tungsten and base metal skarns in the northern cordillera: Canada Geol. Survey, Paper 70-1A, p. 259-266.

Dick, L. A., and Hodgson, C. J., 1982, The MacTung W-Cu(Zn) contact metasomatic and related deposits of the northeastern Canadian cordillera: ECON. GEOL., v. 77, p. 845-867.

Edwards, A. B., Baker, G., and Callow, K. J., 1956, Metamorphism and metasomatism at King Island scheelite mine: Geol. Soc. Australia Jour., v. 3, p. 55-100.

Einaudi, M. T., Meinert, L. D., and Newberry, R. J., 1981, Skarn deposits: ECON. GEOL. 75TH ANNIV. VOL., p. 317-391.

Ellis, J. R., 1983, Characteristics of the quartz-stibnite mineralization and alteration envelope of the new orebody, Lake George antimony deposit, southern New Brunswick: Unpub. B.Sc. thesis, Queen's Univ., Kingston, 69 p.

Foster, R. P., 1977, Solubility of scheelite in hydrothermal chloride solutions: Chem. Geology, v. 20, p. 27-43.

Foster, R. P., Mann, A. G., Armin, T., and Burmeister, B. B., 1978, Richardson's Kop wolframite deposit, Rhodesia: A geochemical model for the hydrothermal behaviour of tungsten: Geol. Soc. South Africa Spec. Pub. 4, p. 107-128.

Gower, S. J., Clark, A. H., and Hodgson, C. J., 1985, Tungstenmolybdenum skarn and stockwork mineralization, Mount ReedMount Haskin district, northern British Columbia, Canada: Canadian Jour. Earth Sci., v. 22, p. 728-747.

Greenwood, H. J., 1975, Buffering of pore fluids by metamorphic reactions: Am. Jour. Sci., v. 275, p. 573-593.

Helgeson, H. C., 1969, Thermodynamics of hydrothermal systems at elevated temperatures and pressures: Am. Jour. Sci., v. 267, p. 729-804.

Helgeson, H. C., Delany, J. M., Nesbitt, H. W., and Bird, D. K., 1978 , Summary and critique of the thermodynamic properties of rock-forming minerals: Am. Jour. Sci., v. 278A, 228 p.

Henley, R. W., 1984a, Hydrolysis reactions in hydrothermal fluids: Rev. Econ. Geology, v. 1, p. 65-82.

$1984 \mathrm{~b}, \mathrm{pH}$ calculations for hydrothermal fluids: Rev. Econ. Geology, v. 1, p. 83-98.

Higgins, N. C., 1980, Fluid inclusion evidence for transport of tungsten by carbonate complexes in hydrothermal solutions: Canadian Jour. Earth Sci., v. 17, p. 823-830.
Holdaway, M. J., 1971, Stability of andalusite and the aluminum silicate phase diagram: Am. Jour. Sci., v. 271, p. 91-131.

Hollister, L. S., and Burruss, R. C., 1976, Phase equilibria in fluid inclusions from the Khtada Lake metamorphic complex: Geochim. et Cosmochim. Acta, v. 40, p. 163-175.

Holloway, J. R., 1984, Graphite- $\mathrm{CH}_{4}-\mathrm{H}_{2} \mathrm{O}-\mathrm{CO}_{2}$ equilibria at lowgrade metamorphic conditions: Geology, v. 12, p. 455-458.

Hsu, L. C., 1977, Effects of oxygen and sulfur fugacities on the scheelite-tungstenite and powellite-molybdenite stability relations: ECON. GEOL., v. 72, p. 664-670.

Ihlen, P. M., 1978, Ore deposits in the north-eastern part of the Oslo region and in the adjacent Precambrian areas, in Neumann, E. R., and Ramberg, I. B., eds., Petrology and geochemistry of continental rifts: Dordrecht, D. Reidel Pub., p. 277-286.

Ihlen, P. M., and Vokes, F. M., 1978, Metallogeny, in Dons, J. A., and Larson, B. J., eds., The Oslo paleorift-a review and guide to excursions: Trondheim, Norges Geol. Undersøkelse, p. 75-90.

Imai, H., Kim, M. Y., Fujiki, Y., and Takenouchi, S., 1978, Geologic structure and fluid inclusion study at the Ohtani and $\mathrm{Ka}$ neuchi mines, Kyoto Prefecture, in Geological studies of the mineral deposits in Japan and East Asia: Tokyo, Univ. Tokyo Press, p. 27-39.

Ishihara, S., 1977, The magnetite-series and ilmenite-series granitic rocks: Mining Geology, v. 27, p. 293-305.

1981, The granitoid series and mineralization: ECON. GEOL. 75TH ANNIV. VOL., p. 458-484.

John, Y. W., 1963, Geology and origin of Sangdong tungsten mine, Republic of Korea: ECON. GEOL., v. 58, p. 1285-1300.

Leake, B. E., 1978, Nomenclature of amphiboles: Canadian Mineralogist, v. 16 , p. $501-520$.

Ludman, A., 1975, Calais-Big Lake map area, Washington County, Maine: Report of mapping progress: Maine Geol. Survey OpenFile Rept., 13 p.

Luth, W. C., Martin, R. F., and Fenn, P. M., 1974, Peralkaline alkali feldspar solvi, in Mackenzie, W. S., and Zussman, J., eds., The feldspars: Manchester England, Manchester Univ. Press, p. 297-312.

Manning, D. A. C., and Henderson, P., 1984, The behaviour of tungsten in granitic melt-vapour systems: Contr. Mineralogy Petrology, v. 85, p. 286-293.

Mathieson, G. A., and Clark, A. H., 1984, The Cantung E zone scheelite skarn orebody, Tungsten, Northwest Territories: A revised genetic model: ECON. GEOL., v. 79, p. 883-901.

Maucher, A., 1965, Die Antimon-Wolfram-Quecksilber-Formation und ihre Beziehungen zu Magmatismus und Geotektonik: Freiberg. Forschungs., v. C 186, p. 173-188.

McCutcheon, S., Lutes, G., Gauthier, G., and Brooks, C., 1981, The Pokiok batholith: A contaminated Acadian intrusion with an anomalous $\mathrm{Rb} / \mathrm{Sr}$ age: Canadian Jour. Earth Sci., v. 18, p. 910-918.

Montoya, J. W., and Hemley, J. J., 1975, Activity relations and stabilities in alkali feldspar and mica alteration reactions: ECON. GEOL., v. 70 , p. $577-583$.

Moon, K. J., 1984, Condition of the Sangdong tungsten skarn formation: Korean Inst. Mining Geology Jour., v. 17, p. 259272.

Moreton, E. P., Clark, A. H., and Peatfield, G. R., 1983, The Boya Claim Group: A tectonically-transported W-Mo stockwork-skarn occurrence, NE British Columbia [abs.]: Geol. Assoc. CanadaMineralog. Assoc. Canada-Canadian Geophys. Union Program with Abstracts, v. 8, p. A48.

Morrissy, C. J., and Ruitenberg, A. A., 1980, Geology of the Lake George antimony deposit, southern New Brunswick: Canadian Mining Metall. Bull. v. 73 , no. 822 , p. 79-84.

Naumov, V. B., and Malinin, S. D., 1968, A new method of determining pressure by means of gas-liquid fluid inclusions: Geochemistry Internat., v. 5, p. 382-391.

Naumov, V. B., Balitskiy, V. S., and Ketchikov, L. N., 1966, Cor- 
relation of temperature of formation, homogenization, and decrepitation of gas fluid inclusions: Akad. Nauk SSSR Doklady, v. 171 , p. $146-148$.

Newberry, R. J., 1983, The formation of subcalcic garnet in scheelite-bearing skarns: Canadian Mineralogist, v. 21 , p. 529544 .

Noble, S. R., Spooner, E. T. C., and Harris, F. R., 1984, The Logtung large tonnage, low-grade W (scheelite)-Mo porphyry deposit, south-central Yukon territory: ECON. GEOL., v. 79, p. 848-868.

Pitcher, W. S., 1983, Granite type and tectonic environment, in Hsü, K. J., ed., Mountain building processes: London, Acad. Press, p. 19-40.

Polkanov, V. T., 1978, The Tirniauz ore-deposits, in Smirnov, V. I., Ore deposits of the U.S.S.R.: Moscow, Nedra, v. 3.

Potter, R. W., II, 1977, Pressure corrections for fluid-inclusion homogenization temperatures based on volumetric properties of the system $\mathrm{NaCl}-\mathrm{H}_{2} \mathrm{O}$ : U. S. Geol. Survey Jour. Research, v. 5, p. 603-607.

Potter, R. W., II, Clynne, M. A., and Brown, D. L., 1978, Freezing point depression in aqueous sodium chloride solutions: ECON. GEOL., v. 73, p. 284-285.

Rock, N. M. S., 1977, The nature and origin of lamprophyres: Some definitions, distinctions, and derivations: Earth-Sci. Rev., v. 13, p. 123-169.

Roedder, E., 1984, Fluid inclusions: Rev. Mineralogy, v. 12, $644 \mathrm{p}$.

Ruitenberg, A. A., and McCutcheon, S. R., 1982, Acadian and Hercynian structural evolution of southern New Brunswick: Geol. Assoc. Canada Spec. Paper 24, p. 131-148.

Ruitenberg, A. A., Fyffe, L. R., McCutcheon, S. R., St. Peter, C. J., Irrinki, R. R., and Venugopal, D. V., 1977, Evolution of pre-Carboniferous tectonostratigraphic zones in the New Brunswick Appalachians: Geosci. Canada, v. 4, p. 171-181.

Scratch, R. B., Watson, G. P., Kerrich, R., and Hutchinson, R. W., 1984, Fracture-controlled antimony-quartz mineralization, Lake George deposit, New Brunswick: Mineralogy, geochemistry, alteration, and hydrothermal regimes: ECON. GEOL., v. 79 , p. 1159-1186.

Seal, R. R., II, 1984, The Lake George W-Mo stockwork deposit, southwestern New Brunswick: Unpub. M.Sc. thesis, Queen's Univ., Kingston, 201 p.

Seal, R. R., II, Archibald, D. A., Clark, A. H., and Farrar, E., 1985a, K-Ar evidence for pre-Devonian orogeny, Lake George area, Fredericton trough, S. W. New Brunswick: Geol. Assoc.
Canada-Mineralog. Assoc. Canada Program with Abstracts, v. 10, p. A-55

Seal, R. R., II, Clark, A. H., and Morrissy, C. J., 1985b, The Lake George polymetallic Sb-W-Mo deposits, southwestern New Brunswick, in Taylor, R. P., and Strong, D. F., eds., Graniterelated mineral deposits-geology, petrogenesis and tectonic setting: Canadian Inst. Mining Metallurgy, Halifax, Nova Scotia, Sept. 1985, Extended Abs., p. 223-225.

- in press, Lake George, S. W. New Brunswick: A Silurian, multi-stage, polymetallic (Sb-W-Mo-Au-base metal) hydrothermal centre: Canadian Inst. Mining Metallurgy Spec. Vol. 39.

Shimazaki, H., 1977, Grossular-spessartine-almandine garnets from some Japanese scheelite skarns: Canadian Mineralogist, v. 15, p. $74-80$.

Smith, R. W., Norman, D. I., and Popp, C. J., 1980, Calculated solubility of molybdenite in hydrothermal solutions [abs.]: Geol. Soc. America Abstracts with Programs, v. 12, p. 525.

Streckeisen, A., 1976, To each plutonic rock its proper name: Earth-Sci. Rev., v. 12, p. 1-33.

Truesdell, A. H., 1984, Chemical geothermometers for geothermal systems: Rev. Econ. Geology, v. 1, p. 31-44.

Tvalchrelidze, G. A., ed., 1982, Ore deposits of the Caucasus; Internat. Assoc. Genesis Ore Deposits Symposium, 6th, Tbilisi, Guidebook, Excursions A-1, A-2, 141 p.

Watson, G. P., 1981, Geology and geochemistry of the alteration zone surrounding quartz-stibnite mineralization, Lake George antimony mine deposit, New Brunswick: Unpub. M.Sc. thesis, Fredericton, Univ. New Brunswick, 240 p.

Wesolowski, D., Drummond, S. E., Mesmer, R. E., and Ohmoto, $\mathrm{H}$., 1982, Tungsten speciation in $\mathrm{NaCl}$ solutions to $300^{\circ} \mathrm{C}$ [abs.]: Geol. Soc. America Abstracts with Programs, v. 14, p. 645.

- 1984, Hydrolysis equilibria of tungsten (VI) in aqueous sodium chloride solutions to $300^{\circ} \mathrm{C}$ : Inorgan. Chemistry, v. 23, p. 1120-1132.

White, A. J. R., and Chappell, B. W., 1977, Ultrametamorphism and granitoid genesis: Tectonophysics, v. 43, p. 7-17.

Williams-Jones, A. E., 1982, Patapedia: An Appalachian calc-silicate-hosted copper prospect of porphyry affinity: Canadian Jour. Earth Sci., v. 19, p. 438-455.

Yan, M.-Z, Wu, L.-L., and Li, C.-Y., 1980, Metallogenetic systems of tungsten in southeast China and their mineralization characteristics: Soc. Mining Geologists Japan Spec. issue 8, p. 215 221 . 